\title{
The Early Devonian acanthodian Euthacanthus macnicoli Powrie, 1864 from the Midland Valley of Scotland
}

\author{
Michael J. NEWMAN \\ Vine Lodge, Vine Road, Johnston, Haverfordwest, \\ Pembrokeshire, SA62 3NZ (United Kingdom) \\ ichthyman@btinternet.com
}

Carole J. BURROW

Ancient Environments, Queensland Museum, 122 Gerler Road, Hendra 4011, Queensland (Australia) carole.burrow@gmail.com

Jan L. DEN BLAAUWEN University of Amsterdam, Science Park 904, 1098 XH, Amsterdam (Netherlands) j.I.denblaauwen@uva.nl

Robert G. DAVIDSON 35 Millside Road, Peterculter, Aberdeen, AB14 OWG (United Kingdom) Bob_G_Davidson@nexeninc.com

KEY WORDS Lochkovian, Acanthodii, Euthacanthidae, Euthacanthus, scale histology, fin spine histology.
Newman M. J., Burrow C. J., Den Blaauwen J. L. \& Davidson R. G. 2014. - The Early Devonian acanthodian Euthacanthus macnicoli Powrie, 1864 from the Midland Valley of Scotland. Geodiversitas 36 (3): 321-348. http://dx.doi.org/10.5252/g2014n3a1

\section{ABSTRACT}

The five species of genus Euthacanthus Powrie, 1864 are reduced to two species on morphological and stratigraphical evidence. Euthacanthus macnicoli Powrie, 1864 and Euthacanthus grandis Powrie, 1870 are here synonymised in the type species E. macnicoli Powrie, 1864. In a previous article, Euthacanthus gracilis Powrie, 1870 and Euthacanthus elegans Powrie, 1870 were combined in the species E. gracilis, and the fifth species, Euthacanthus curtus Powrie, 1870, was reassigned to Uraniacanthus curtus (Powrie, 1870). In this work, we give an in-depth study of the full range of morphological and histological structure of scales over the body of E. macnicoli, as well as of fin spine structure. Our study reveals new features of E. macnicoli, including a large ornamented dorsal sclerotic bone, ornament on the branchiostegal plates, a separate series of gular rays, calcified cartilage forming the jaws, and a postbranchial protruding spinose plate rather than the flat prepectoral plate previously described. 


\author{
MOTS CLÉS \\ Lochkovien, \\ Acanthodii, \\ Euthacanthidae, \\ Euthacanthus, \\ échelle histologie, \\ nageoire épine histologie.
}

\begin{abstract}
RÉSUMÉ
L'acanthodien Euthacanthus macnicoli Powrie, 1864, du Dévonien inférieur de la vallée Midland, Écosse.

Les cinq espèces connues du genre Euthacanthus Powrie, 1864 sont réduites à deux espèces sur la base de données morphologiques et stratigraphiques. Euthacanthus grandis Powrie, 1870 est placée ici en synonymie avec l'espèce type du genre, E. macnicoli, de même qu'Euthacanthus elegans Powrie, 1870 avait été placée en synonymie avec l'espèce $E$. gracilis dans une précédente publication. La cinquième espèce, Euthacanthus curtus Powrie, 1870, avait déjà été réassignée à Uraniacanthus curtus (Powrie, 1870). Dans ce travail, nous menons une étude approfondie de l'ensemble des structures morphologiques et histologiques des écailles et des épines de E. macnicoli. Notre étude révèle de nouveaux caractères anatomiques chez E. macnicoli, incluant un grand os sclérotique dorsal ornementé, une ornementation sur les plaques branchiostèges, une série distincte de rayons gulaires, du cartilage calcifié composant les mâchoires, et une plaque épineuse postbranchiale saillante en lieu et place de la plaque prépectorale peu élevée précédemment décrite.
\end{abstract}

\section{INTRODUCTION}

The general history of the discovery of fossil fishes in the Midland Valley of Scotland was detailed by Davidson \& Newman (2003) and Newman et al. (2011). In 1864 Powrie raised the genus Euthacanthus Powrie, 1864 with type and only species Euthacanthus macnicoli Powrie, 1864 based on an articulated fish from the Lochkovian slates of Tillywhandland Quarry, Forfarshire. The specific name honoured local collector Walter M'Nicoll (18271908; Fig. 1A) who collected many of the specimens accumulated by Powrie. Powrie commissioned Louis Agassiz's illustrator Joseph Dinkel to provide a figure of the holotype NMS G.1891.92.231 (Powrie 1864: pl. 20, fig. 2a; reproduced in Fig. 1B). Powrie (1870) later raised the species Euthacanthus gracilis Powrie, 1870, Euthacanthus elegans Powrie, 1870, Euthacanthus curtus Powrie, 1870 and Euthacanthus grandis Powrie, 1870. The first three of the latter species were recently redescribed and revised by Newman et al. (2011, 2012). Powrie (1870: pl. 9, fig. 3; Fig. 1C) provided crude pen and ink figures including a reconstruction of E. macnicoli, and later (Powrie 1881) provided another very brief descrip- tion of all his species of Euthacanthus in a general description of the fossils of Forfarshire. At the end of the nineteenth and beginning of the twentieth centuries the validity of the genus Euthacanthus was debated, with several workers considering it a junior synonym of Climatius Agassiz, 1845 (see Newman et al. 2011). Dean (1907: fig. 23) briefly described the fin spines and scales of E. macnicoli, figuring the posterior dorsal fin spine of one specimen (NHM P.38597, wrongly transcribed as NHM P.35907). No more detailed studies of Euthacanthus were undertaken until Watson's (1937) monograph on the acanthodian fishes. He also retained E. macnicoli in the genus Euthacanthus as he considered there were fundamental morphological differences between it and Climatius. His reconstruction (Watson 1937: fig. 4A; Fig. 1D) is the one generally found in text books. Later authors dealt with the higher classification of Euthacanthus but with little consensus (Newman et al. 2011). In Miles' (1973) monograph on Lower Old Red Sandstone acanthodians he provided a useful description of the shoulder girdle of E. macnicoli. Denison (1979: figs 10A, 17C) was the first to illustrate and describe the scale histology and morphology in 

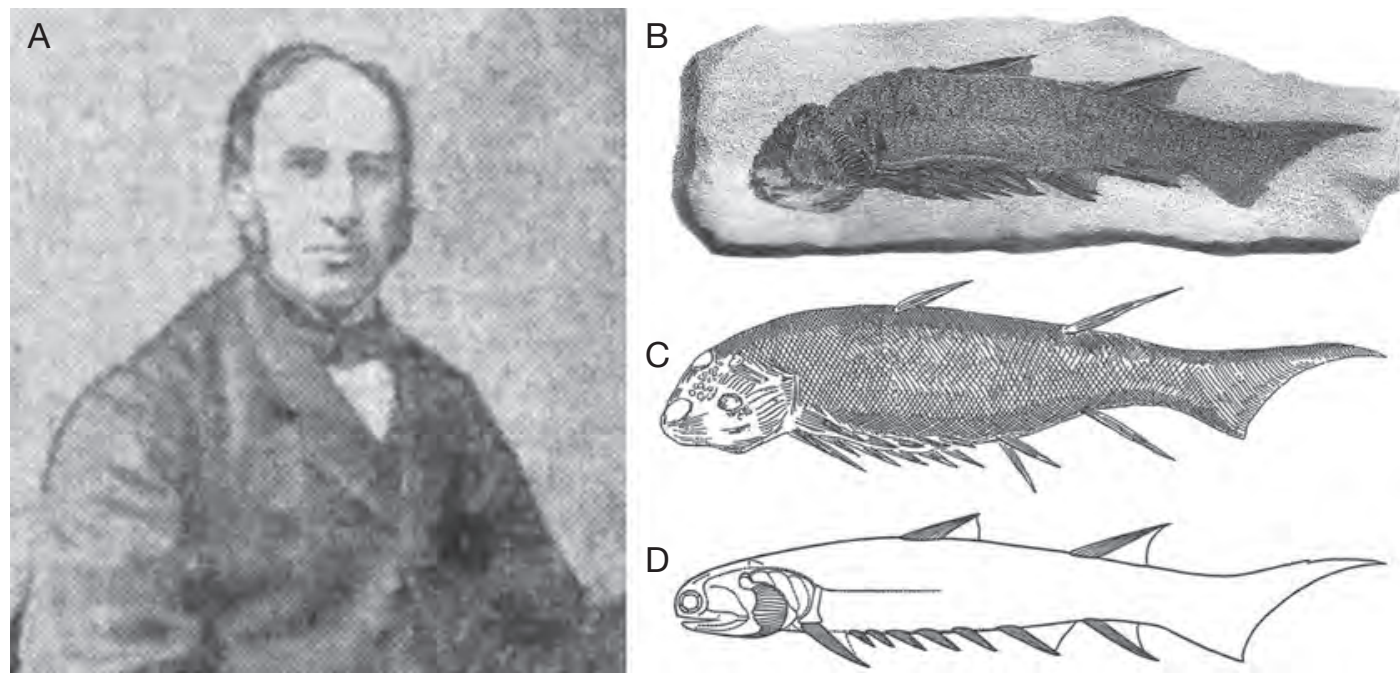

FIG. 1. - A, Walter M'Nicoll (1827-1908); B-D, previously published reconstructions of Euthacanthus macnicoli Powrie, 1864; B, Powrie 1864: pl. 20, fig. 2; C, Powrie 1870: pl. 11, fig. 3; D, Watson 1937: fig. 4.

E. macnicoli. Young (1995) described the variation in scale ornament in E. macnicoli in scales from three different areas of the body, noting that the larger scales near the middle of the body had more grooves and ridges than scales elsewhere. Burrow \& Young (1999) recorded the ratios of the distances between the pectoral, pelvic and anal fin spines in a number of acanthodians including E. macnicoli.

The first cladistic analysis of the Acanthodii by Hanke \& Wilson (2004), which demonstrated the paraphyly of the Order Climatiiformes, concluded that $E$. macnicoli did not belong in the family Climatiidae. The cladistic analysis of early gnathostome relationships by Brazeau (2009) indicated that the Acanthodii were paraphyletic, with E. macnicoli resolved as basal to the Acanthodiformes in the stem osteichthyan lineage. However, none of the nodes in Brazeau's analysis that are relevant to this acanthodian paraphyly were strongly supported, and he has since stated that the relationships of Ptomacanthus Miles, 1973 (traditionally considered to be a climatiid acanthodian), the core taxon in his analysis which he described at the time as "the most basal chondrichthyan or as the sister group of all living gnathostomes" (Brazeau 2009: 305), now "remains difficult to place on either the chondrichthyan, osteichthyan or gnathostome stem" (Brazeau 2012: 355). A more recent analysis by Davis et al. (2012: fig. 4; strict consensus of 512 shortest cladograms) resolved Euthacanthus as the most basal stem osteichthyan, the sister group to Ischnacanthiformes + Acanthodiformes + Dialipina + Ligulalepis + crown osteichthyans. In contrast, the latest cladistic analysis by Zhu et al. (2013) produced consensus trees with acanthodians as a paraphyletic assemblage assigned to the chondrichthyan stem group, with this combined assemblage being a sister group to a monophyletic Osteichthyes. However, both of the recent analyses include 23 acanthodians, with Davis et al. (2012) adding Lupopsyrus Bernacsek \& Dineley, 1977, Rhadinacanthus Traquair, 1888 and Vernicomacanthus Miles, 1973 to the taxa used by Brazeau (2009). Vernicomacanthus is a rare taxon which is poorly known (Miles 1973) and Rhadinacanthus has barely been mentioned since the 1900s, but is presently under study by our group. Data codings were not updated by Davis et al. (2012) and Zhu et al. (2013) from several recent papers on acanthodian taxa used in their analyses (e.g., Newman et al. 2011, 2012; Brazeau 2012; Hanke \& Davis 2012; Burrow et al. 2013), and a revised analysis is 
being undertaken, based on data in these publications and our own work in progress. Preliminary results show a traditional, monophyletic Acanthodii in a trichotomy with Chondrichthyes and Osteichthyes, but clearly the relationships between these groups remains controversial.

Given the lack of consensus on acanthodian relationships both within the group and with other early gnathostomes, we tentatively retain Euthacanthus in the "traditional" Class Acanthodii. Here we provide an updated description of E. macnicoli including detailed information on scale variation over the body, and the morphology and histology of scales and fin spines. Our in depth illustration and description of scales from small, medium and large individuals, made possible by dismembering and/or thin sectioning articulated specimens before their gifting to institutional collections, is one of the most extensive such studies completed for any acanthodian species.

\section{MATERIAL AND METHODS}

Full stratigraphic and geographical details of the Forfarshire Lower Devonian localities are given in two recent papers by Burrow \& Turner (2010) and Newman et al. (2011). Articulated examples of Euthacanthus are not common at any locality, with most specimens having come from Turin Hill (Tillywhandland) near Forfar in the Scottish Midland Valley. Most were collected in the nineteenth century, with only a few specimens added to institutional collections since, as the best opportunity for collection was during active quarrying operations. The only sites which have yielded material since the nineteenth century are Tillywhandland Quarry on the east side of Turin Hill, and Balruddery Den and Duntrune Quarry, both near Dundee. The Tillywhandland site yields rare articulated Euthacanthus macnicoli and, more commonly, disarticulated remains of apparently larger individuals (based on fin spine size) of this species. Balruddery Den has started to yield poorly preserved articulated examples of this species and associated fauna. In the 1960s and 70s, Dr W. Graham-Smith collected articulated specimens from Duntrune Quarry, but none have been collected there since.
All specimens used in this study are housed in the National Museums of Scotland, Edinburgh (NMS), the Natural History Museum in London (NHM) and the Queensland Museum (QMF).

The comparative work in this study is based on microscopic examination of structure and ornament of fin spines and scales and a reevaluation of general morphology of specimens assigned to Euthacanthus macnicoli and E. grandis. Powrie's (1864, 1870) original descriptions as well as those by more recent workers are reviewed. Macro-photographs were taken of all specimens using a Canon EOS 450D. Microphotographs were made under normal light using a Wild M420 binocular microscope with a Sony DSC-H2 camera. Thin sections were made using epoxy resin and various sizes of corundum grinding powder down to 4 microns with photographs taken using a Sony DSC-H2 camera attached to a Nikon Eclipse E 400 microscope. Serial thin sections were drawn from enlarged photographs with acetate over the top. Patches of scales were immersed in weak acetic acid to separate individual scales for scanning electron microscopy using a JEOL JSM-6300F scanning electron microscope (SEM) housed in the Centre for Microscopy and Microanalysis, Brisbane, Australia. Figures were compiled using Adobe Photoshop ${ }^{\circledR}$.

A range of different sized specimens of Euthacanthus macnicoli from Tillywhandland Quarry were chosen for preparation by the destructive techniques described above. An articulated specimen of average size (NMS G.2013.8.1), minus most of the head, was chosen for serial thin sectioning to show the histological scale variation along the whole body. Another partial articulated specimen NMS G.2010.7.42, complete from the posterior dorsal and anal fin spine insertions to the tip of the tail, was also serially thin sectioned and small blocks of the squamation were cut and imaged in the SEM; individual scales were also extracted and imaged. NMS G.2010.7.39 is the part and counterpart of a large individual that would previously have been described as Euthacanthus grandis. Fragments were broken off the part as the matrix was slightly calcareous and weathered, and treated with acetic acid to isolate individual scales for SEM imaging. Later, the whole part was immersed in acid to remove scales and clean the 
larger bone elements so that their morphology is better revealed. Also, multiple thin sections were made through scales in the ventral region of the counterpart and sections were made of several isolated scales. Some of the larger bone elements on the part were imaged under SEM and light microscope. NMS G.2010.7.43 and NMS G.2010.7.41, both coprolite/regurgitate masses of elements from large individuals, were thin sectioned and some scales and other bony elements imaged under the SEM. Normal light microscope images were also taken of the scales on NMS G.2010.7.43.

\section{SYSTEMATICS}

\section{Class ACANTHODII Owen, 1846}

\section{Family EuTHACANTHIDAE Berg, 1940}

TyPe AND Only Genus. - Euthacanthus Powrie, 1864.

DiAgnosis. - Acanthodians lacking an oral dentition; ring of five sclerotic bones; closeset branchiostegal plates over part of the branchial region; dermal pectoral girdle comprises a single pair of triangular postbranchial plates, each with one spine, that are not contiguous with the scapulocoracoid; simple scapulocoracoid with a columnar shaft; scapulocoracoid is covered laterally only by normal body scales, not dermal tesserae; anterior dorsal, posterior dorsal, anal, pectoral and pelvic fin spines are robust with thick walls and a wide pulp canal, and longitudinal ornament ridges; four to six pairs of prepelvic spines; polygonal tectal tesserae.

\section{REMARKS}

Cladistic analyses (e.g., Hanke \& Wilson 2004; Brazeau 2009; Burrow \& Turner 2010; Davis et al. 2012; Zhu et al. 2013) have shown that the order Climatiiformes sensu Denison (1979) is paraphyletic, and Euthacanthus does not fall into other recognized orders. Berg (1940) raised the family Euthacanthidae to incorporate Euthacanthus and possibly Brachyacanthus Egerton, 1860, and Miles (1966) also considered that Euthacanthus and Brachyacanthus were members of the same family as both forms have no teeth and a principle gill cover that did not cover the whole gill chamber. Newman et al. (2011) excluded Brachyacanthus from the Euthacanthidae based on the fin spine ridge ornamentation, and as none of the recent cladistic analyses support a sister relationship between Euthacanthus and Brachyacanthus (or any other genera) we consider the Euthacanthidae to be a monogeneric family.

\section{Genus Euthacanthus Powrie, 1864}

TYPE SPECIES. - Euthacanthus macnicoli Powrie, 1864 by original designation.

INCLUDED SPECIES. - Euthacanthus macnicoli Powrie, 1864; E. gracilis Powrie, 1870.

Geologic And Geographic Distribution. - Early Devonian (Early Lochkovian) of the Midland Valley of Scotland.

REVISED DIAGNOSIS. - Medium-sized, fusiform fish with maximum length to depth ratio $5: 1$; jaws formed of calcified cartilage; slender closeset branchiostegal plates; fin spines relatively slender and straight with smooth longitudinal ridges separated by deep smooth grooves; four or five pairs of prepelvic spines; posterior dorsal fin spine longer than anterior dorsal fin spine; scales ornamented with subparallel rounded ridges leading back from the anterior edge of the crown, with a slightly convex base.

\section{REMARKS}

When Powrie (1864) first described Euthacanthus macnicoli he had only one complete specimen at his disposal, the holotype NMS G.1891.92.231 from Turin Hill (although he mentioned no locality at this time). Powrie (1864) also stated that he had disarticulated remains which indicated that the species grew quite large and that some of the remains showed that another species was present. Later, Powrie (1870) stated that his first specimens of E. macnicoli came from Farnell and Tealing, though no remains from these localities in his collection can be said with confidence to belong to this species. Articulated Euthacanthus specimens from these localities are now assigned to $E$. gracilis (Newman et al. 2011). Powrie (1864) believed that all the fish beds at the different localities constituted one continuous lake deposit, hence he assigned any disarticulated remains to his first named species, E. macnicoli. However, Armstrong \& Paterson (1970) demonstrated that the fossil fish localities are at various stratigraphic horizons. 
Powrie (1870) stated that he had two reasonably complete specimens of E. macnicoli and that these came from Turin Hill. In the same publication, he raised another species, Euthacanthus grandis, which he said only occurred at Turin Hill. Powrie (1870) differentiated $E$. grandis from E. macnicoli by the relative size of the fin spines, with the former having shorter fin spines relative to body size. However, the specimens Powrie (1870) assigned to E. grandis were much larger than the specimens he assigned to E. macnicoli. Very few studies have been made in acanthodian species that compare the ratio of fin spine length to total length of the fish. As far as we can determine, Acanthodes Agassiz, 1833 and Lodeacanthus Upeniece, 1996 are the only genera in which such work has been undertaken. Zidek (1976: table 2C-E; 1985: table 1d-g) showed that in Acanthodes bridgei Zidek, 1976 and also A. lundi Zidek, 1980, the ratio of fin spine length to total specimen length showed no allometry, i.e. the ratio was approximately the same in fish of all sizes. In contrast, Upeniece (2011: table 5.26) showed that relative fin spine lengths in Lodeacanthus vary remarkably during ontogeny, but the variation between spine length and fish length appears random not allometric (Upeniece 2011: fig. 5.4). In at least some of the species of LORS acanthodians including E. macnicoli, the fin spines grew at a slower rate than the body, so that proportionally, larger specimens of a given species have smaller fin spines. This phenomenon was first recognised, as far as we know, by W. Graham-Smith (unpublished correspondence held in the Perth Museum and Art Gallery, Scotland) and confirmed by the authors in many species. The allometric growth of the fin spines relative to body length in E. macnicoli (using the posterior dorsal fin spine, which is most often the best preserved spine) is illustrated in Fig. 2.

Powrie (1870) also differentiated between the two species by $E$. grandis having larger scales with more grooves and ridges. Because acanthodian "onionskin-type growth" scales continued to increase in size while the fish itself grew (e.g., Zidek 1976, 1985), it is hardly surprising to see larger scales in larger individuals. Like Acanthodes fin spines, and unlike Euthacanthus fin spines, "scale size relative to the total specimen size is remarkably similar in most... Acanthodes species" (Zidek 1985: 164). We consider $E$. grandis to be an advanced growth stage of $E$. macnicoli, and can recognize no specific differences between the two forms.

The head and branchial region is not well preserved (if at all) in specimens of Euthacanthus gracilis. However, NMS G.1891.92.243 (Newman et al. 2011: fig. 7A) shows several subparallel thick rods behind the jaws that are most likely to be branchiostegal plates; this specimen also has displaced sclerotic bones preserved above the jaws. We have thus revised the family diagnosis.

\section{Euthacanthus macnicoli Powrie, 1864}

(Figs 1-19)

Euthacanthus macnicoli Powrie, 1864: 425, pl. 20, fig. 2; 1870: 290, pl. 11, figs 3, 3a, 3b; 1881: 169. - Anonymous 1867: 7, fig. 1. — Barkas 1874: 550. — Traquair 1892: 33. — Dean 1907: 216, figs 23, 36. — Watson 1937: 61, figs 3, 4, pl. 7, figs 1, 2. — Adams \& Eddy 1949: fig. 11. - Lehman 1959: fig. 22. — Heyler 1969b: 59, figs 1, 20. — Miles 1970: 362. — Moy-Thomas \& Miles 1971: figs 4.2, 4.6. - Miles 1973: 183, fig. 36, pl. 15, fig. 1. - Paton 1976: 7. - Jarvik 1977: 212, fig. 11B. - Denison 1979: 27, figs 4A, 10A, 11A, 17C. - Young 1995: 66, fig. 5.

Euthacanthus grandis Powrie, 1870: 292, pl. 12, fig. 6; 1881: 169. - Barkas 1874: 550. - Traquair 1892: 33. — Gunther 1904: 312. — Miles 1970:362. — Paton 1976: 6.

Climatius grandis - Woodward \& Sherborn 1890: 36, 81. — Woodward 1891: 31. — Dean 1907: 218, fig. 30. — O'Connell 1916: 90.

Climatius macnicoli - Woodward \& Sherborn 1890: 36, 81. - Woodward 1891: 30. — O'Connell 1916: 90. - Graham-Smith 1936: 596.

Euthacanthus - Traquair 1894: 257. - Hay 1902: 274. - Heyler 1969a: 40, 42, 43, 49. - Halstead 1969: fig. 17a. - Moy-Thomas \& Miles 1971: 61, 69, 70, 71. — Long 1986: 336, fig. 10. — Frickhinger 1991: 239. - Janvier 1996: 177. - Trewin \& Davidson 1996: 233, 241. - Benton 1997: fig. 3.14b. - Prothero 1998: fig. 17.23. - Wilson \& Anderson 2004: 171. — Hanke \& Wilson 2006: 534, 535. — Miller 2007: 994. — Park \& Gierlowski-Kordesch 2007: 165. - Brazeau 2009: fig. 3. - Franz-Odendaal 2011: 394. — Hanke \& Davis 2012: 480, fig. 7A, B. — Davis et al. 2012: fig. 4. —Zhu et al. 2013: fig. 6 . 


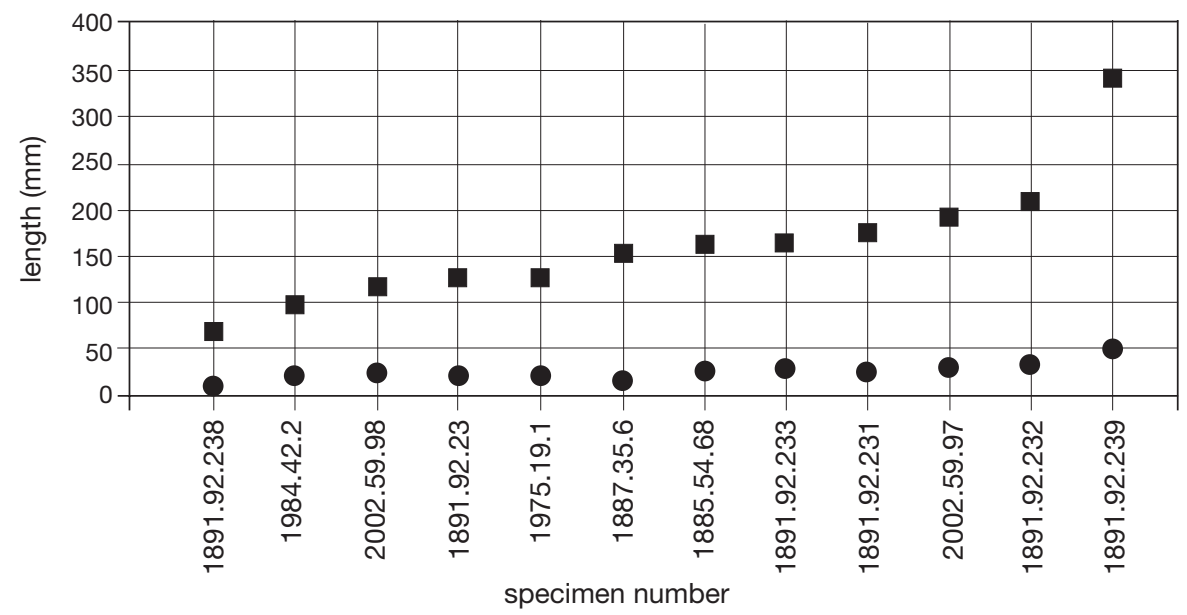

FIG. 2. - Euthacanthus macnicoli Powrie, 1864: comparison of length of fish compared with length of posterior dorsal fin spine, for 12 near complete specimens. Symbols: $\bullet$, pdfs length $(\mathrm{mm}) ; \mathbf{\square}$, fish length $(\mathrm{mm})$.

Euthacanthus mitchelli - Goodchild 1904: 597. — O’Connell 1916: 90, 175.

Euthacanthus macnicolli $[$ sic] - Moy-Thomas 1939: fig. 8A. - Frickhinger 1991: 239, fig. caption.

Euthacanthus macnicoli - Burrow \& Young 1999: 10. - Gagnier et al. 1999: 93. — Dineley 1999: 159, figs 5.6B, C, 5.8C. — Davidson \& Newman 2003: 244. - Hanke \& Wilson 2004: 189. — Valiukevičius \& Burrow 2005: 636. - Hanke \& Davis 2008: 318; 2012: 480, 482. — Newman et al. 2011: 101; 2012: 740. - Brazeau 2012: 356.

TYPE SPECIMEN. - NMS G.1891.92.231 and the counterpart NHM P.1337 (near complete specimen missing the snout).

REFERRED SPECIMENS. - Over 50 articulated or partial articulated specimens have been identified by the authors in public museums and private collections. The largest collection of specimens is in the National Museums of Scotland. Furthermore, many hundreds of specimens consisting of disarticulated fin spines and scales have been observed by the authors; in this state of preservation the species could be considered common. Apart from the holotype, studied specimens include: from Turin Hill, NMS G.1881.5.60, NMS G.1885.54.6B, NMS G.1887.35.6A, NMS G.1891.92.236, NMS G.1891.92.238, NMS G.1891.92.275, NMS G.1967.12.5; from Tillywhandland, NHM P.67308, NMS G.2007.24.2, NMS G.2010.7.39, NMS G.2010.7.41, NMS G.2010.7.42, NMS G.2010.7.43, NMS G.2013.8.1, QMF57175,
QMF57176; from Duntrune, NMS G.2002.59.97, NMS G.2002.59.100; from Balruddery Den, NMS G.2011.33.1.

Type LOCALITY. - Tillywhandland Quarry (National Grid reference NO 528 537) near Forfar, Scotland. Tillywhandland Quarry is part of the Turin Hill complex of quarries and it is thought that most specimens recorded as coming from Turin Hill were collected there (Trewin \& Davidson 1996).

STRATIGRAPHIC HORIZON AND AGE. - Upper part of the Arbuthnott Group of the Lower Devonian (Lochkovian) of the Strathmore Region of Scotland.

Occurrence. - Tillywhandland; Balruddery Den (National Grid reference NO 314 325) and Duntrune Quarry (National Grid reference NO 438 352) both just north of Dundee, Scotland.

ReVised Diagnosis. - Euthacanthus with large polygonal tesserae covering the dorsal surface of the head forward of the hyoid region; five circumorbital plates with the uppermost plate being largest, and ornamented with sinuous radiating nodose ridges; at least two external nares surrounded by small plates; small scales cover the cheek region; at least seven closeset branchiostegal plates above the angle of the jaw and five or more closeset branchiostegal plates below the angle of the jaw that cover the anterior branchial region; branchiostegal plates have an ornament comprising both short inclined or conical tubercles and long subparallel sinuous ridges; three subsidiary gill covers posterodorsal to these plates; 

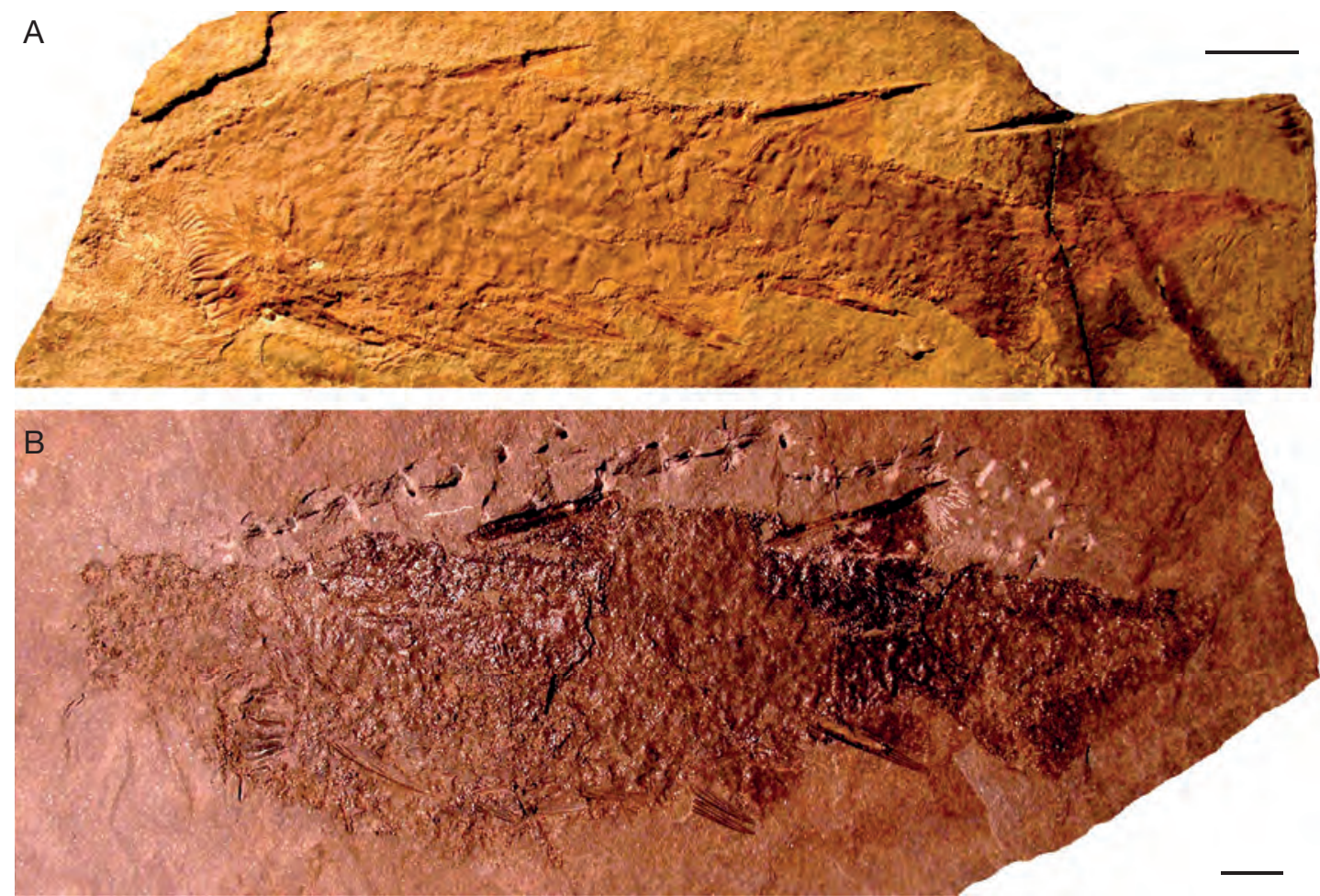

FIG. 3. - Euthacanthus macnicoli Powrie, 1864: A, NMS G.1891.92.231 from Turin Hill (Tillywhandland), the holotype; B, NMS G.2002.59.97, a moderate sized individual from Duntrune. Scale bars: $10 \mathrm{~mm}$.

scapula shaped like an inverted letter $\mathrm{T}$ with a smooth and straight lower edge; paired ventral postbranchial plates spine-shaped, ornamented with apically-directed nodose ridges on the lateral side and irregular tubercles medially; posterior dorsal fin spine is approximately opposite the anal fin spine; leading edge ridge on fin spines is fully rounded, with lateral ridges having a gently curving upper surface separated by a sharp edge from a lower/posterior surface curving steeply down into the groove; scales have subparallel deep grooves and ridges at the anterior end of the crown with the number of grooves ranging between five to twenty depending on the size of the scale; scales along the lateral line are the same size as normal flank scales; scale crowns comprise superposed growth zones with wide radial, ascending and circular vascular canals, Stranggewebe filling the primordial and posterior parts of the crown growth zones, and simple mesodentine filling the anterior parts of the growth zones; scale bases are slightly convex and formed of cellular bone with simple Sharpey's fibres extending from the base apex to the lower surface of the base.

\section{DESCRIPTION}

\section{General features}

Of the fifty or more articulated specimens known, nearly all are laterally compressed apart from NMS G.1891.92.275 (only the front third is preserved) and NMS G.2007.24.2, which are dorsoventrally compressed, and NMS G.1891.92.238, which is ventrodorsally compressed. NMS G.2002.59.100 is compressed laterally although the head has twisted to show it in a ventral view. Collection specimens vary in size from $100 \mathrm{~mm}$ to an estimated $450 \mathrm{~mm}$ long (based on isolated large fin spines and an articulated specimen c. $430 \mathrm{~mm}$ long in the private collection of Roger Jones of Geneva). The holotype (NMS G.1891.92.231; Fig. 3A) differs slightly from most other specimens in being more slender, with Duntrune specimen NMS G.2002.59.97 (Fig. 3B) representing the average body shape. 



FIG. 4. - Euthacanthus macnicoli Powrie, 1864, head and branchial region: A, holotype NMS G.1891.92.231 from Turin Hill; B, NMS G.1891.92.236 from Turin Hill; C, NMS G.2011.33.1 from Balruddery Den; D, NMS G.2002.59.97 from Duntrune. Abbreviations: gr, gular rays; It.br.p, left side branchiostegal plates; It.II, left side lateral line; It.sb, left sclerotic bones; It.sc, left scapulocoracoid; p.fs, pectoral fin spine; rt.br.p, right side branchiostegal plates; rt.II, right side lateral line; rt.pp.p, right "prepectoral plate"; rt.sb, right side sclerotic bones; rt.sc, right scapulocoracoid; sgc1, first subsidiary gill cover; sgc2, second subsidiary gill cover; sgc3, third subsidiary gill cover. Scale bars: $5 \mathrm{~mm}$.

The species is fusiform with a maximum depth to length ratio of about 0.2 . There are four (e.g., NMS G.2002.59.97) or five prepelvic fin spines (e.g., NMS G.1891.92.231). Watson (1937: 65) stated that one specimen he observed (he did not say which one) had six prepelvic fin spines on one side of the fish, but we have not seen any such specimens and suspect this is a misinterpretation or a pathological aberration rather than a general character. The posterior dorsal fin spine is oppo- site or nearly opposite the anal fin spine, and the anterior dorsal fin spine is positioned far behind the level of the pectoral fin spines, opposite the midpoint of the prepelvic fin spine series.

\section{Head and branchial region}

Many specimens show elements of the head but they are usually disarticulated and poorly preserved. Some of the best preserved examples are the holotype NMS G.1891.92.231 (Fig. 4A) 


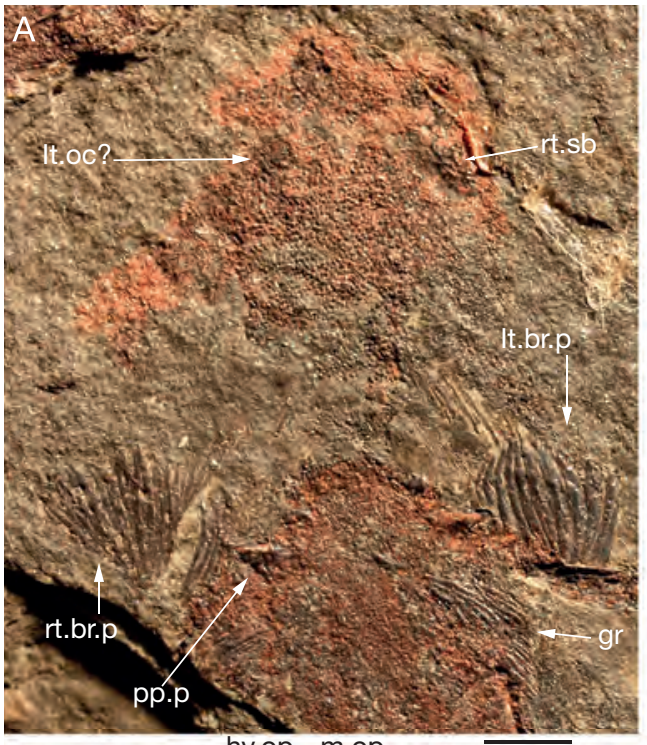

hy.op m.op

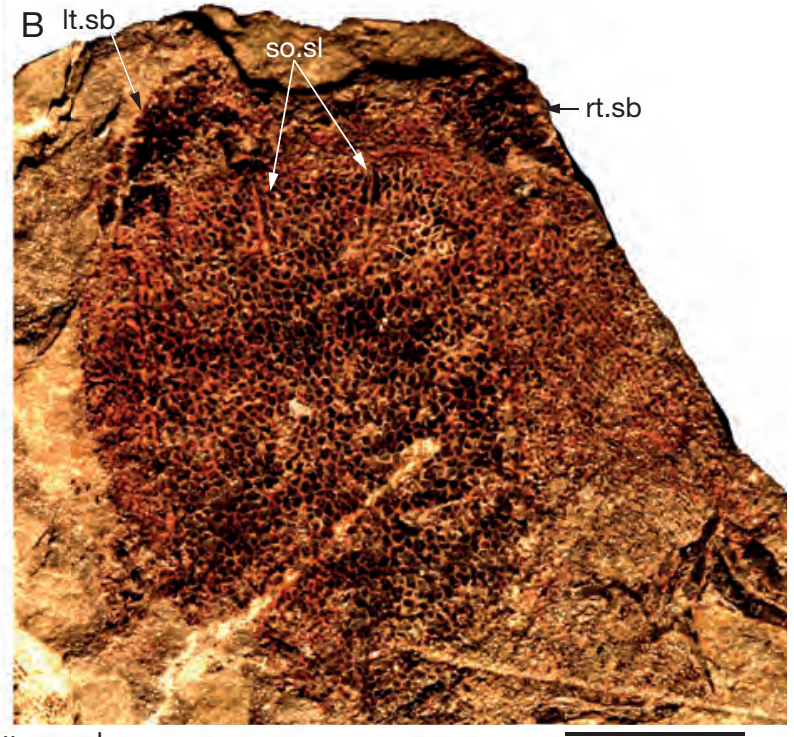

$\mathrm{sb}$
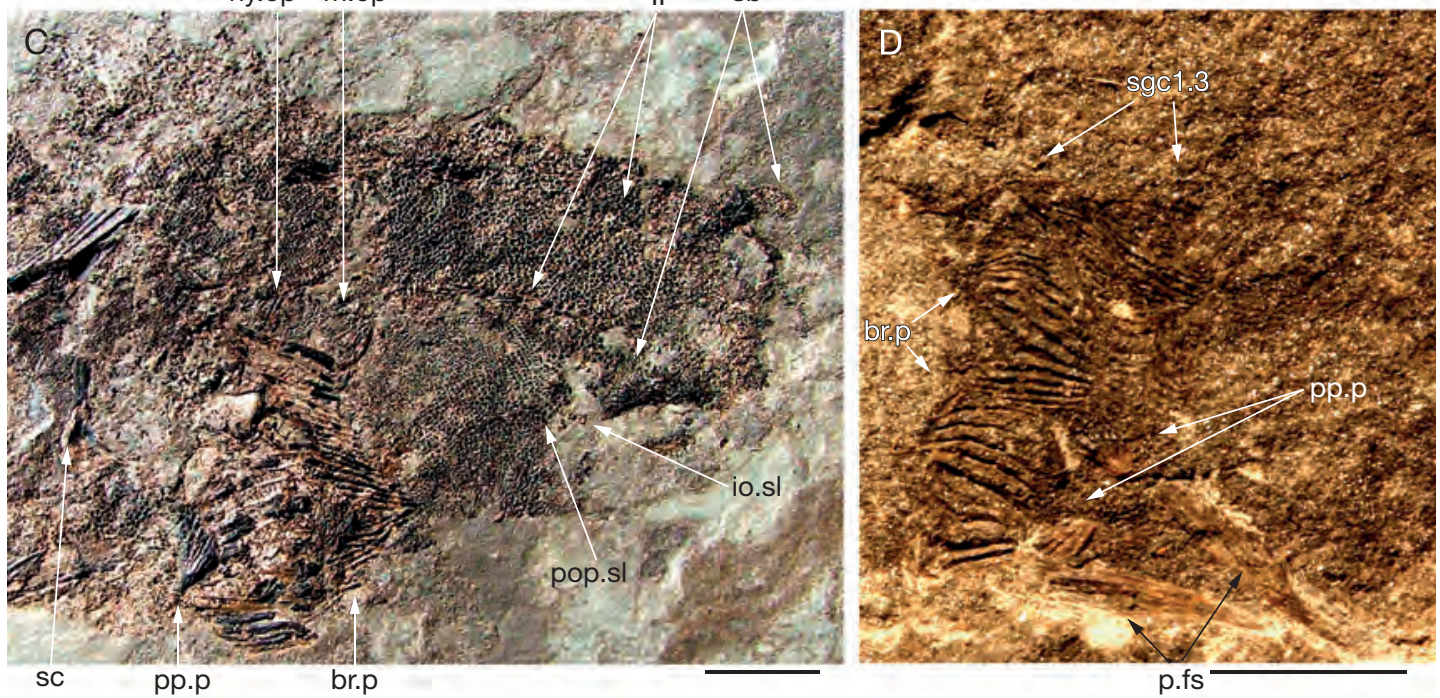

FIG. 5. - Euthacanthus macnicoli Powrie, 1864, head and branchial region: A, NMS G.1891.92.238 from Turin Hill; B, NMS G.1891.92.275 from Turin Hill; C, NMS G.2007.24.2 from Tillywhandland; D, NMS G.2002.59.100 from Duntrune. Abbreviations: br.p, branchiostegal plates; gr, gular rays; hy.op, hyoid operculum; io.sl, infraorbital sensory line canal; II, lateral line; It.br.p, left branchiostegal plates; It.oc, left otic capsule; It.sb, left sclerotic bone; m.op, mandibular operculum; p.fs, pectoral fin spine; pop.c, preopercular sensory line canal; pop.sl, preopercular sensory line; pp.p, "prepectoral plate"; rt.br.p, right branchiostegal plates; rt.sb, right sclerotic bones; sb, sclerotic bone; sc, scapulocoracoid; so.sl, supraorbital sensory line canal; sgc1-3, first to third subsidiary gill covers. Scale bars: $5 \mathrm{~mm}$.

and NMS G.1891.92.236 (Fig. 4B) from Turin Hill, NMS G.2002.59.97 (Fig. 4C) from Duntrune and NMS G.2011.33.1 (Fig. 4D) from Balruddery. The ventral surface of the body is exposed on NMS G.1891.92.238 (Fig. 5A), but the jaws appear to have been lost exposing the inner surface of the tectal squamation and sclerotic bones, and a visceral view of the pectoral region. NMS G.1891.92.275 (Fig. 5B) from Turin Hill shows the head and branchial region preserved in 

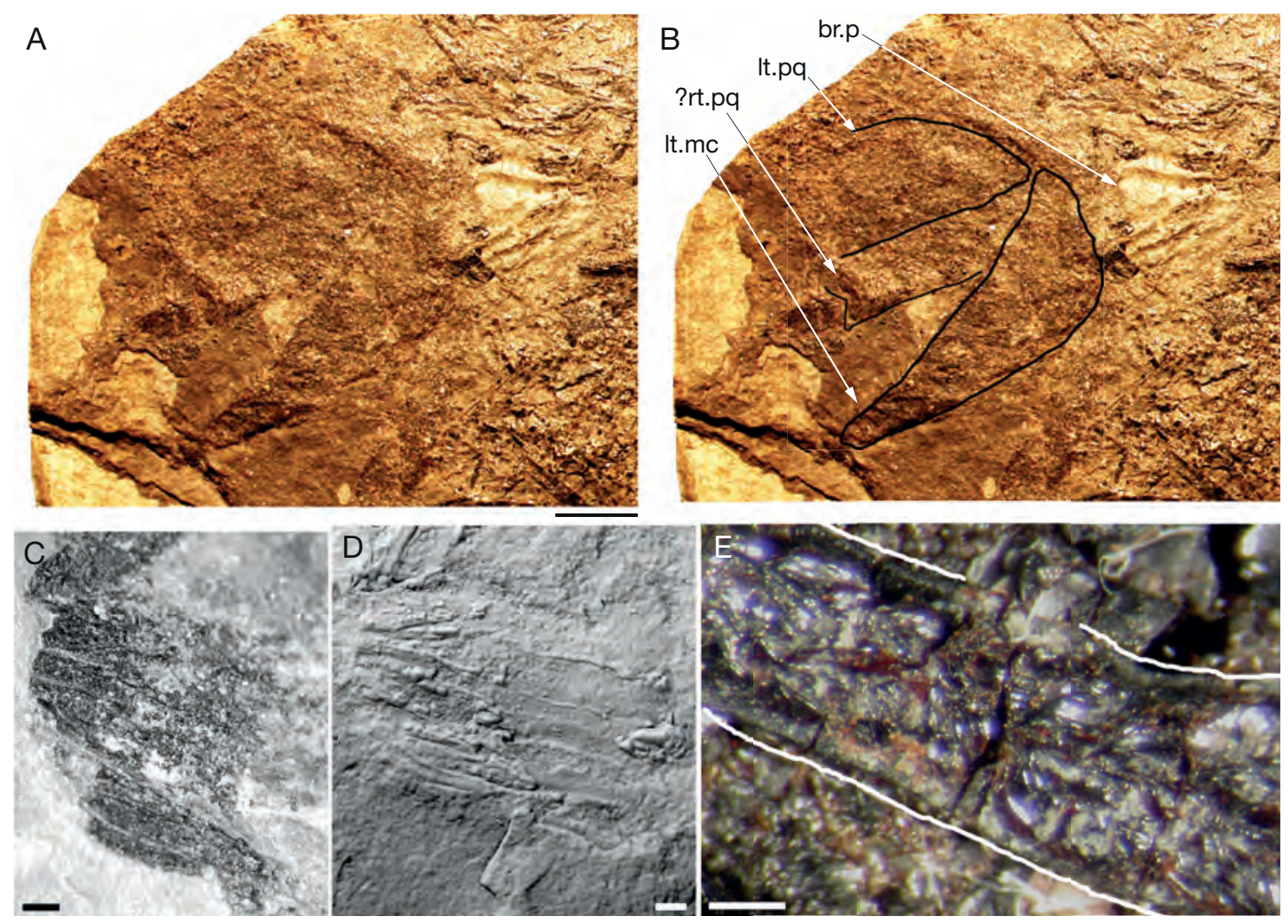

FIG. 6. - Euthacanthus macnicoli Powrie, 1864, jaws and branchiostegal plate ornament: A, NMS G.1967.12.7 from Turin Hill (Tillywhandland); C, D, branchiostegal plates on QMF57176 from Tillywhandland, under normal light (C) and whitened with magnesium oxide (D); E, branchiostegal plate in NHM P.67308, a large regurgitate or coprolite. Abbreviations: br.p, branchiostegal plates; It.mc, left Meckel's cartilage; It.pq, left palatoquadrate cartilage; rt.pq, right palatoquadrate cartilage. Scale bars: A, B, 10 mm; C-E, 1 mm.

dorsal view, and on NMS G.2007.24.2 (Fig. 5C) from Tillywhandland, the head is exposed in dorsal view. NMS G.2002.59.100 (Fig. 5D) from Duntrune is a rare specimen showing the branchial region and some of the head preserved in ventral view. Whereas Watson (1937) stated that the neurocranium and visceral skeleton were unossified and never preserved, we note that at least some elements of the endocranium and visceral skeleton were composed of globular calcified cartilage globules, preserved in situ on rare articulated specimens (e.g., NMS G1967.12.7) and as patches visible in some thin sections and scattered amongst the dermal structures (e.g., NMS G.2010.7.39). On NMS G.1967.12.7 (Fig. 6A), the upper and lower jaws are preserved by granular mineralization of the cartilages. The lower jaws have dropped off most specimens before burial, as is common with most LORS acanthodians (Burrow et al. 2013). Teeth are absent from both the upper and lower jaw.

Large dermal bones are only present in the orbital and branchial regions. The eyes are very far forward, with a ring of five robust bones of which the most dorsal one is markedly larger than the others (Figs 4A, D; 5C). The bones are convex radially as well as laterally and ornamented with noded sinuous ridges that sometimes bifurcate. There are no sensory lines present on any of the orbital bones and, contra Watson (1937), these are interpreted as sclerotic rather than circumorbital bones (see Burrow et al. 2011). 


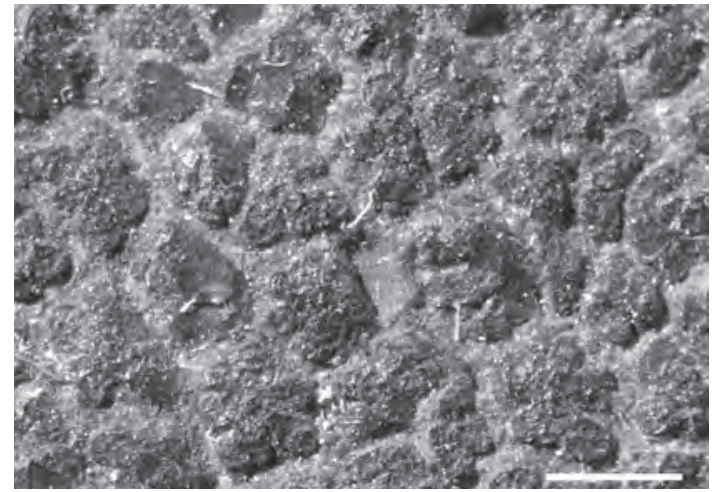

FIG. 7. - Euthacanthus macnicoli Powrie, 1864, head tesserae: NMS G.1881.5.60 from Turin Hill. Scale bar: $1 \mathrm{~mm}$.

Euthacanthus macnicoli has a very blunt snout terminating just in front of the orbits (Fig. 5A, C). Two circular objects preserved as impressions behind the eyes on NMS G.1891.92.238 (Fig. 5A) could represent the otic capsules.

The dorsal surface of the head is covered with dermal tesserae circa $0.5 \mathrm{~mm}$ wide in between the main lateral lines, and larger, more polygonal tesserae c. $1.0 \mathrm{~mm}$ anteriorly as shown in NMS G.1881.5.60 (Fig. 7) from Turin Hill. In the cheek region between the orbits and the branchial chamber are small scales that progressively decrease in size from the ventral anterior to the posterior dorsal. This area is particularly well preserved in NMS G.2007.24.2 (Fig. 5C), with scales aligned in posteroventral to anterodorsal rows. The posterior dorsal cheek region abuts the subcircular mandibular operculum (sensu Watson 1937), which is covered with small rod like scales that are larger than the scales of the cheek region. The rest of the relatively long branchial region is well preserved on a number of specimens, and was described in detail by Watson (1937). The anterior branchial region has a dermal cover comprising up to 25 slender plates. Following the designation of Hanke \& Wilson (2004), these are divisible into a series above the angle of the jaw and another series below the angle of the jaw; the widest and longest rays are those near the jaw articulation. These robust dermal plates appear smooth on the holotype; Watson (1937) described these elements as unornamented, but we suggest that his description was based on specimens in which the outer layer was lost when the specimen was split and/or he was looking at the smooth internal surfaces, as ornament is visible on several other articulated specimens (e.g., Fig. 5D). The ornament consists of tubercles and long sinuous ridges running subparallel to the edges of the branchiostegal plates, giving them a rugose surface. The tubercles are irregular in form, with some being conical and forming short rows such as on QMF57175 and QMF57176 (Fig. 6B, C), and others short and inclined as on disassociated plates in the acidprepared regurgitate/coprolite NHM P.67308 (Fig. 6D). The branchiostegal rays become much thinner on the ventral side of the fish in the gular region, as exemplified on NMS G.1891.92.238 (Fig. 5A) which is preserved ventral side up. This specimen also shows separate areas of thinner rays oriented obliquely across each side between the branchiostegal series. Possibly when the jaws fell off the specimen, the skin and gular rays remained behind but were flipped backwards. As noted by Watson (1937), there are three well-defined postopercular branchial arches. In NMS G.1891.92.231 (Fig. 4A) and NMS G.1891.92.236 (Fig. 4B) the gill septa are covered by a series of moderately long, narrow rods that curve posteriorly at their ventral ends. Additional rods are inserted between the upper ends of these rods before the curvature, creating a narrow gill cover. These subsidiary gill covers are better preserved in NMS G 1891.92.238 (Fig. 5A), NMS G.2011.33.1 (Fig. 4D) and NMS G.2002.59.100 (Fig. 5D). In these specimens the rods are positioned more horizontally and are closer packed, forming a continuous covering. On NMS G.2002.59.100 (Fig. 5D), the small specimen with ventral surface exposed, both the pectoral fin spines and the postbranchial spinose plates are preserved in position. The rods and plates of the first and second subsidiary gill covers extend down to the edge of the postbranchial plate; all three posterior gill slits are of equal length, but the posteriormost subsidiary gill cover is shallower than the other two.

The sensory lines on the head are preserved as a gap between rows of rod-like scales or plates (Fig. 5B, 5C), and their layout was well described 

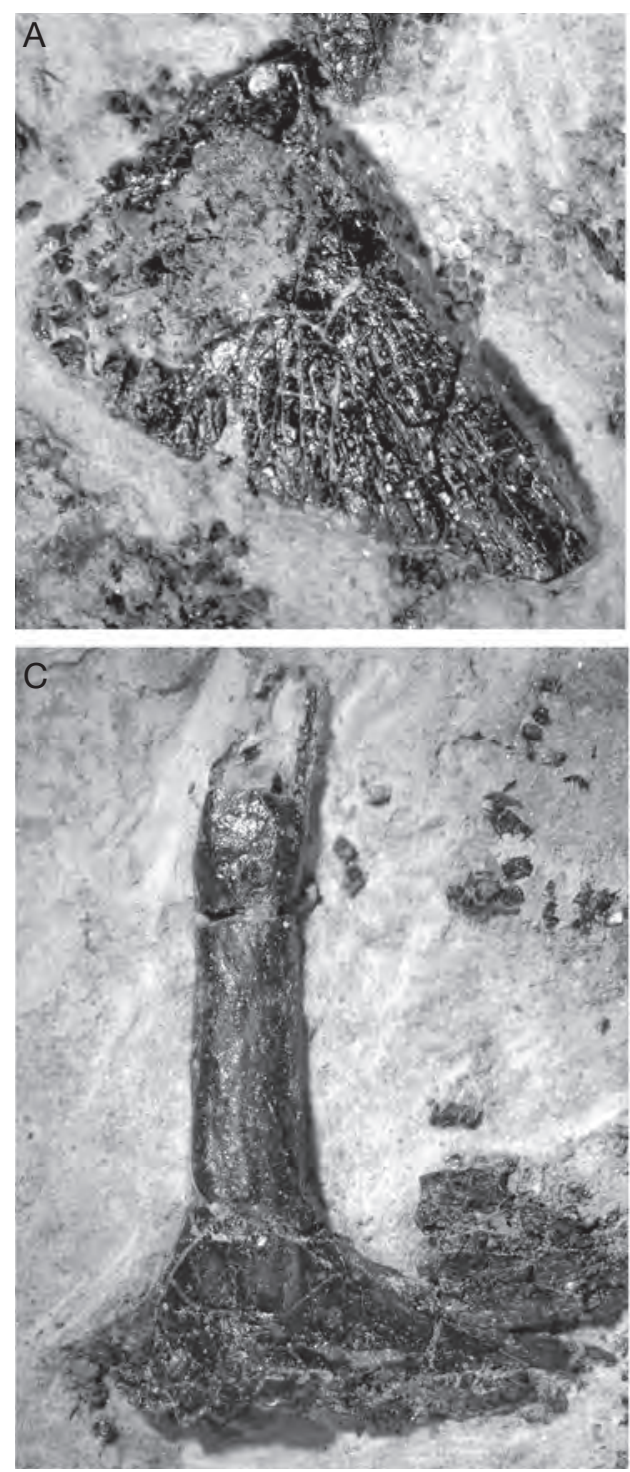
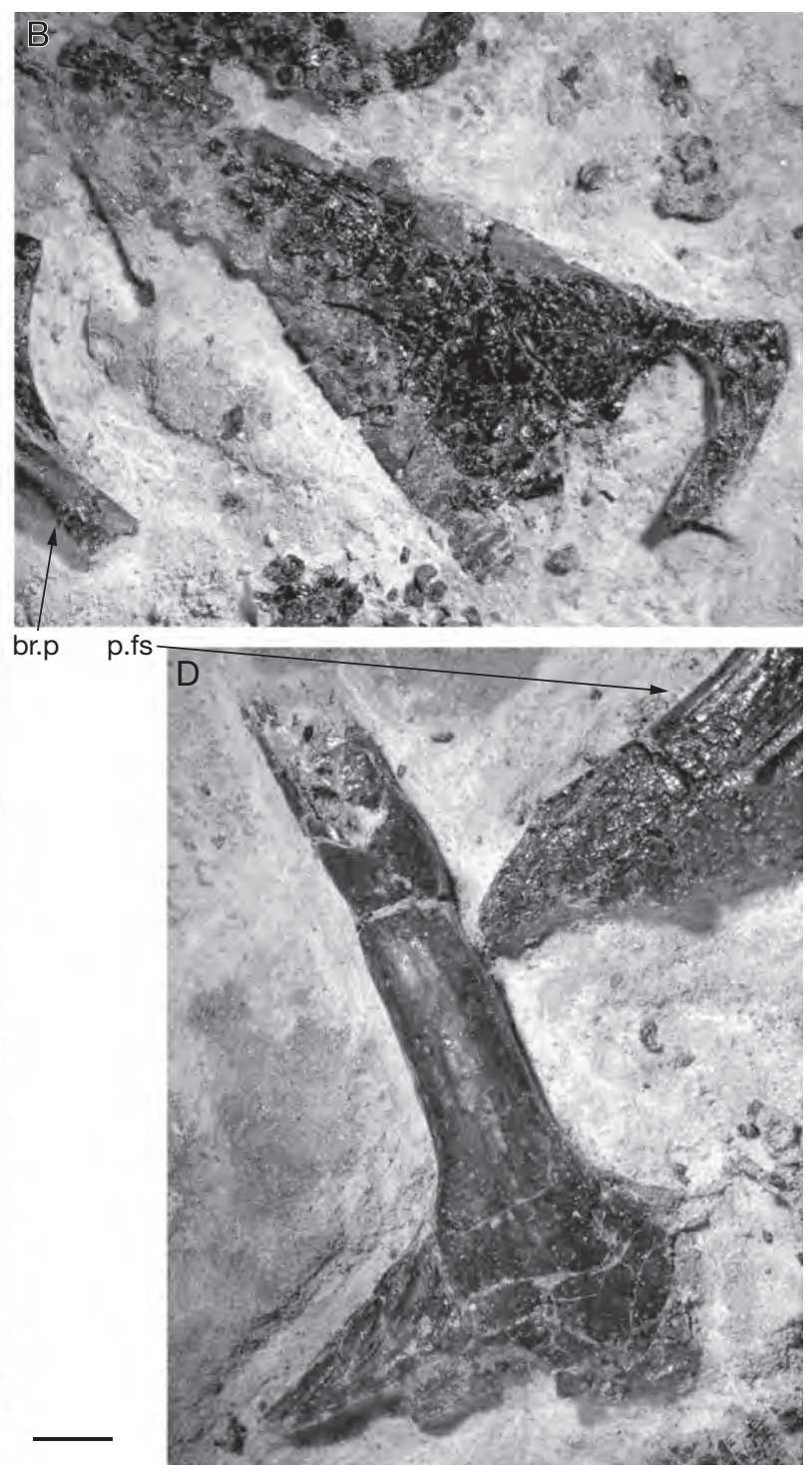

FIG. 8. - Euthacanthus macnicoli Powrie, 1864, shoulder girdle elements on NMS G.2010.7.39: A, left prepectoral plate; B, right prepectoral plate, medial surface; $\mathbf{C}$, left scapulocoracoid, lateral surface; $\mathbf{D}$, right scapulocoracoid, lateral surface. Abbreviations: br.p, branchiostegal plates; p.fs, pectoral fin spine. Scale bar: $2 \mathrm{~mm}$.

by Watson (1937: fig. 3, pl. 7, fig. 2). However, we consider that the structures that Watson labelled as mandibular canal, oral canal and supramaxillary are probably not sensory lines, but the outlines of the jaw cartilages (Fig. 6A). We still recognize a preopercular canal that more or less follows the upper edge of the palatoquadrate.

\section{Pectoral region}

A pair of robust triangular plates with a spinose projection are positioned anteromedially to each of the pectoral fin spines (Fig. 5C, D). Watson (1937: fig. 4B) referred to these structures as antero-lateral pectoral dermal bones. Their lateral ornamentation comprises broad tubercles that 


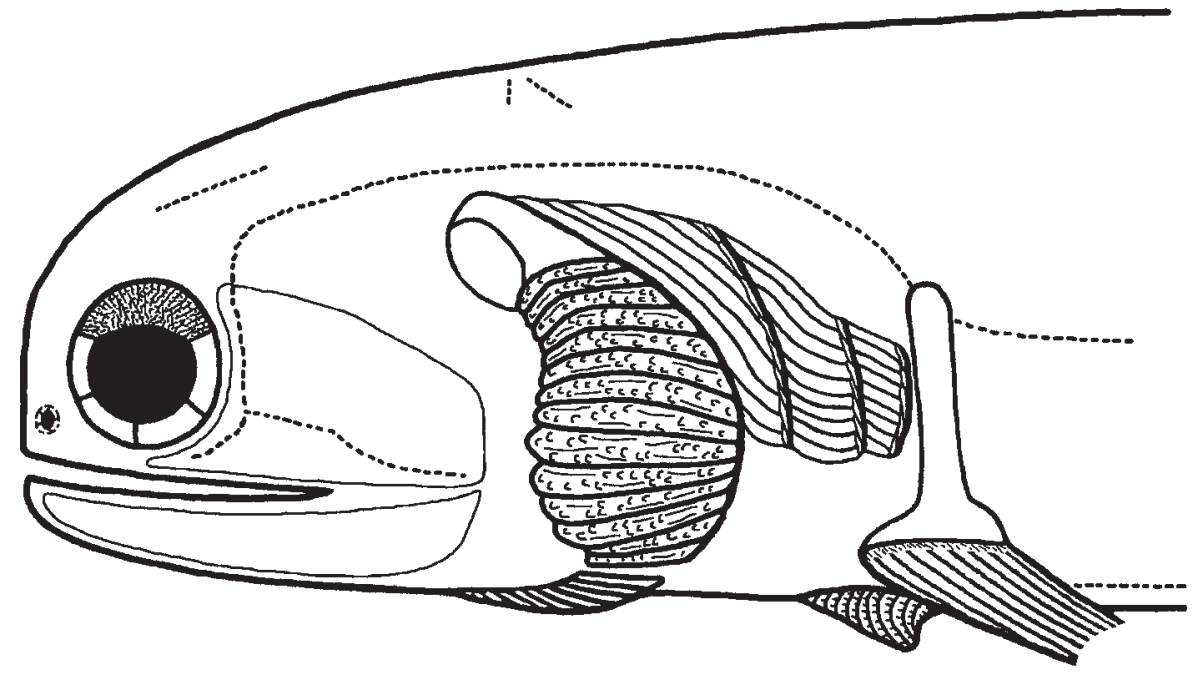

FIG. 9. - Euthacanthus macnicoli Powrie, 1864. Reconstruction of the head in lateral view, much modified after Watson (1937, fig. 3).

run in rows to the apex and coalesce in places into ridges, with these ridges becoming finer towards the spine tip (Figs 4B; 8A). The medial surfaces of these "plates" are also ornamented, with more irregularly placed tubercles (Fig. 8B). Miles (1973) described the structures as pinnal plates and interpreted the spine projection as prepectoral spine three, and also stated that the posterolateral edge of the plate was bevelled as in Parexus Agassiz, 1845 and Vernicomacanthus. Although characterized as a spine-bearing plate, its preservation in the dorsoventrally compressed specimens (Figs 5A, D) and ornamentation on both sides show that it was more spine-like than plate-like in life, projecting down from the body of the fish. Their preservation sometimes between the pectoral fin spines suggests that these plates could be admedian rather than prepectoral structures, but as the plates are usually displaced we are not certain of their homology and continue referring to them as prepectoral plates.
The scapulocoracoid is a simple structure comprising a columnar scapular shaft expanding sharply to a triangular area with a flat lower edge articulating with the base of the pectoral fin spine (Fig. 8C, D).

Figure 9 is a new reconstruction of the head, branchial and pectoral regions of Euthacanthus macnicoli in lateral view, based on Watson (1937: fig. 4) and incorporating our reinterpretation of some of the morphological features.

\section{Fin spines}

In general the fin spines are of moderate length and thickness with short bases. From splitting of the fish-bearing blocks, the fin spines are often fractured lengthwise showing the cores rather than the surface ornament. Where the ornament is preserved, it consists of smooth, longitudinal ridges and deep grooves (Fig. 10A, B). The grooves terminate along the leading edge toward the tip of the spine. The posterior dorsal fin spine (Fig. 10A) is longest, with $c$. seven ridges and grooves on each

FIG. 10. - Euthacanthus macnicoli Powrie, 1864 fin spines: A, NMS G.1967.12.5 from Turin Hill, posterior and anterior dorsal fin spines; B, NMS G.1885.54.6B, anal fin spine; C, NMS G.2002.59.27p, lower half of an articulated fish showing the fin spines; D-I, ground thin sections of fin spines on NMS G.2010.7.42; D-F, cross-sections of an anal fin spine; D, near the tip of the fin spine with no pulp cavity; E, showing vascular canals of the middle layer, and lamellar bone forming inner layer lining central cavity; $\mathbf{F}$, mid-proximal end of spine, with open central cavity open along leading edge; G-I, thin sections of posterior dorsal fin spine; G, mid-distal end of spine with closed central cavity; $\mathbf{H}$, leading edge ridge with mesodentine forming ridge, osteodentine forming middle layer, and very thin 

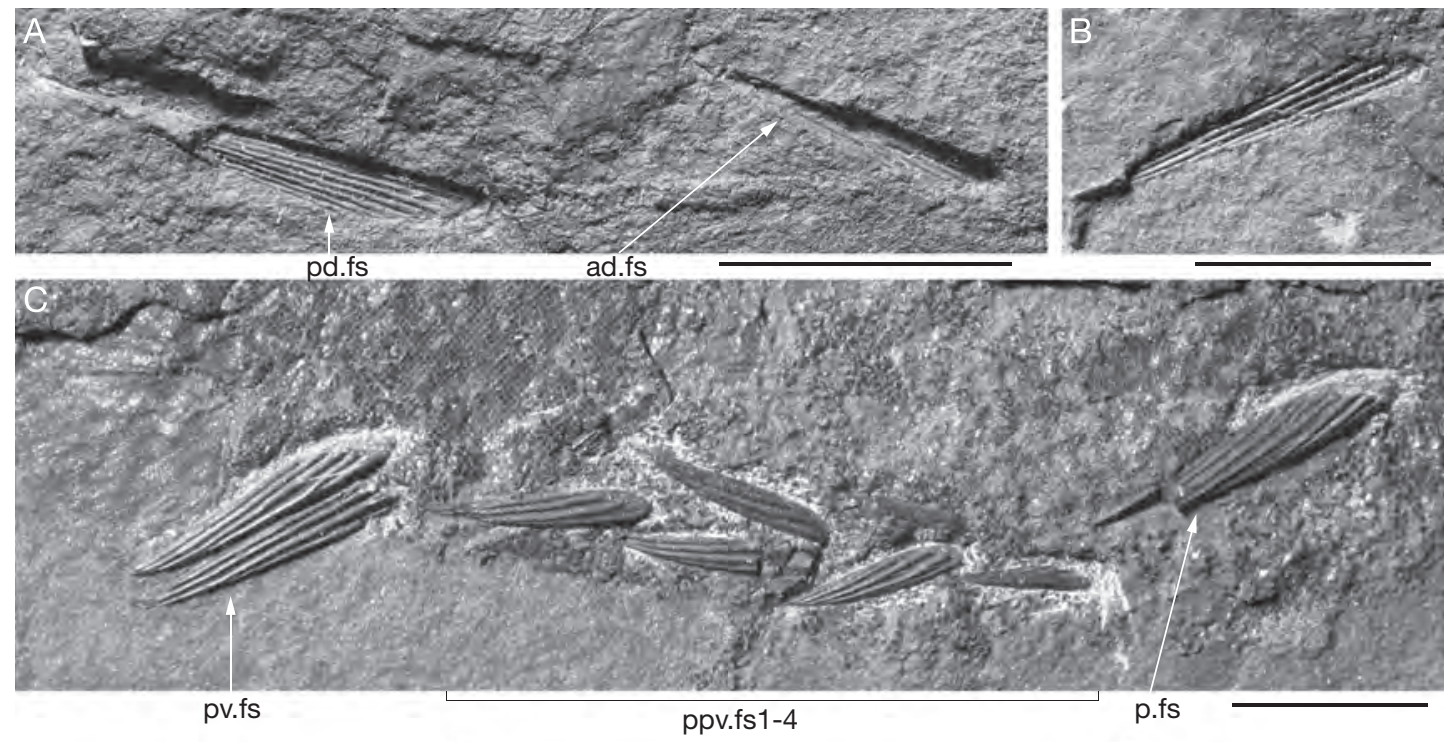



E

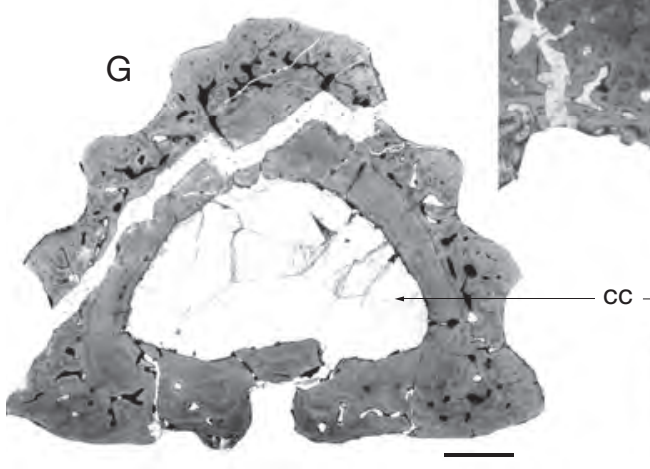

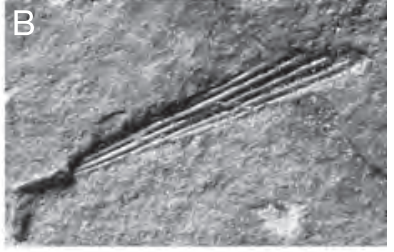

.



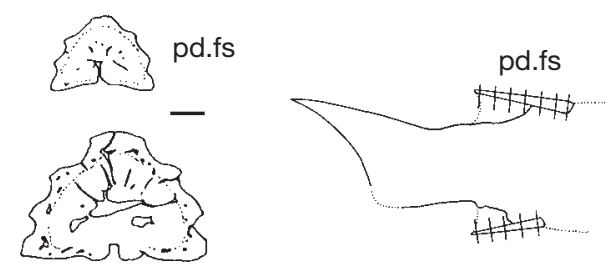

a.fs

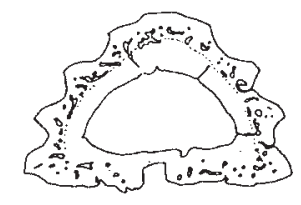

a.fs
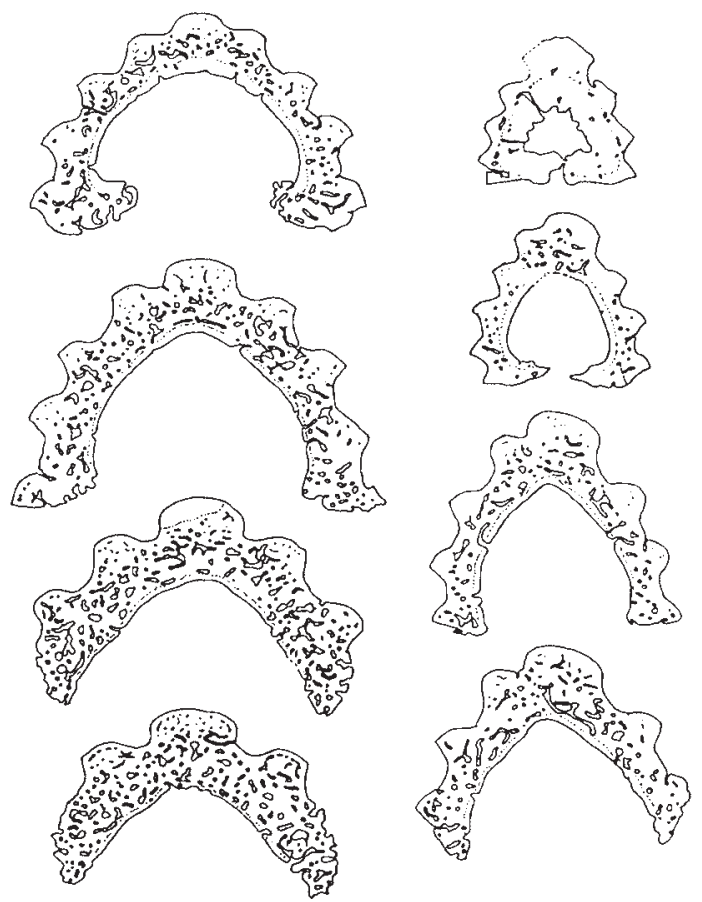

FIG. 11. - Euthacanthus macnicoli Powrie, 1864, fin spine histological structure: Serial sections of posterior dorsal (pd.fs) and anal (a.fs) fin spines of NMS G.2010.7.42. Scale bar: $0.25 \mathrm{~mm}$.

side of the straight fin spine. The anterior dorsal fin spine is only slightly shorter, with $c$. five ridges and grooves on each side of the spine. The anal fin spine (Fig. 10B) is slightly shorter than the anterior dorsal fin spine, straight, and quite thin, with four or five ridges and grooves on each side of the fin spine. The pectoral fin spine (Fig. 10C) is slightly curved, shorter than the anal fin spine, with a rela- tively long base compared with the other fin spines, and usually having six ridges and grooves on each side of the spine. The pelvic fin spines (Fig. 10C) have four ridges per side, are a similar length to the pectoral spines, and are about twice as long as the largest prepelvic fin spine. The prepelvic spines (Fig. 10C) decrease in length towards the anterior. Four ridges and grooves on each side of the spine converge at the tip, and the spines are strongly laterally compressed and slightly curved.

Thin sections through the anal and posterior dorsal fin spines on NMS G.2010.7.42 (Figs 10D-I; 11) show variations in the cross-sectional shape of the ridges and infilling of the central pulp cavity between the base and the tip. Near the tip, the ridges are sharp-crested (Fig. 10D), becoming more rounded toward the base (Fig. 10F); the pulp cavity is wholly infilled by bone (Figs 10D, I; 11) at the distal end, and wide open toward the spine base. Through most of the length of the spine, a dense lamellar layer lines the inner surface (Fig. 10E), overlain by thick osteodentine that extends into the ridges (Figs 10H; 11). Only a thin outer layer is devoid of the wide vascular canal network penetrating the spine.

\section{Squamation}

The caudal fin shows a similar pattern to that of Acanthodes described by Heyler (1969a, b) and expanded on by Miles (1970). The notch on the tail of Watson's (1937: fig. 4A) reconstruction is a preservational artifact caused by the separation of zone Z2 from Zone Z2". The only difference between Miles's (1970: fig. 7) reconstruction of the tail zonation of Acanthodes and that of Euthacanthus macnicoli (Fig. 12) is a further subdivision being present in the latter at the anterior end of the hypochordal lobe, which has scales which are notably larger than the surrounding scales. Miles (1970) also noted this feature in the Early Devonian acanthodians Ischnacanthus gracilis (Egerton, 1861) and Mesacanthus mitchelli (Egerton, 1860), as did Dean (1907) in the Early Devonian acanthodian Parexus recurvus Agassiz 1844. Later, Miles (1973: text-fig. 3) described the same condition in Early Devonian acanthodian Ptomacanthus anglicus Miles, 1973 and denoted this Zone Z3". Zone 



FIG. 12. - Euthacanthus macnicoli Powrie, 1864, tail squamation: A, tail of holotype NMS G.1891.92.231; B, squamation pattern in E. macnicoli, based on that for Acanthodes sp. as figured by Miles (1970: fig. 7). Scale bar: $10 \mathrm{~mm}$.

Z1 consists of scales of the caudal prolongation of the trunk and are typical body scales. Zone Z3 and zone $\mathrm{Z} 4$ are separated only by a transitional boundary, with Zone Z4 having smaller scales than Zone Z3. Zone Z2 consists of a thin strip of scales on the dorsal edge of the tail. Zone Z2 has a 45 degree rotation of enlarged scales in comparison to zone $\mathrm{Z} 1$. This rotation is reversed in Zone Z2" where the scales are much smaller than in Zone Z1.

Miles (1973: pl. 15, fig. 1) described lepidotrichia-like scale rows on a pectoral fin web of NMS G.1971.38. This specimen was assigned by Miles (1973) to Euthacanthus sp. but belongs in the species Euthacanthus macnicoli as there is a large portion of the body trunk preserved, but no sign of the enlarged lateral line scales that characterize Euthacanthus gracilis (Newman et al. 2011). Other specimens of E. macnicoli show the same character, e.g., NMS G.1891.92.240.

\section{Scales}

The scales range in length from $0.5-2 \mathrm{~mm}$. The crown is ornamented with deep furrows and ridges leading back from the anterior edge. On moderate sized individuals such as NMS G.2013.8.1 (Fig. 13A) from Tillywhandland, normal flank scales show only slight morphological variation over the length of the body. Scales in the pectoral and anterior dorsal region consistently have four strong parallel ridges running the full length of the crown (Fig. 13B). Mid-body scales also have four ridges, but these are less robust and fade out past the centre of the crown (Fig. 13C). Mid-flank scales between the posterior dorsal and anal fin spines have only two or three short, weakly developed ridges, with shallow grooves between them (Fig. 13D). Scales mid-tail are almost smooth, with only two very weak short ridges anteromedially on the crown (Fig. 13E).

The thin sections made from NMS G.2013.8.1 (Fig. 14) show that all the normal body scales have three to five crown growth zones, with Stranggewebe (sensu Gross 1971: mesodentine comprising parallel tubules extending between vascular canals) filling the primordial and posterior parts of the crown growth zones, and simple mesodentine filling the anterior parts of the growth zones. Growth zones are not visible in the base; rounded to oval bone cell lacunae are relatively densely and evenly distributed through the base of all scales, and simple Sharpey's fibres extend from the base apex to the lower surface of the base. Wide radial, circular and ascending vascular canals form a network throughout the crown, with the ascending canals extending back below the crown surface grooves. Scales in the pectoral and anterior dorsal regions have a relatively flat base (Fig. 14A-E), midbody scale bases are slightly more convex (Fig. 14F-H), and caudal scales have the most convex bases (Fig. 14I$\mathrm{N})$. The scale structure conforms to the Nostolepis sensu stricto type as defined by Valiukevičius \& Burrow (2005).

NMS G.2010.7.42 is the articulated tail, plus dorsal and anal fin spines (Fig. 15A) from a fairly 


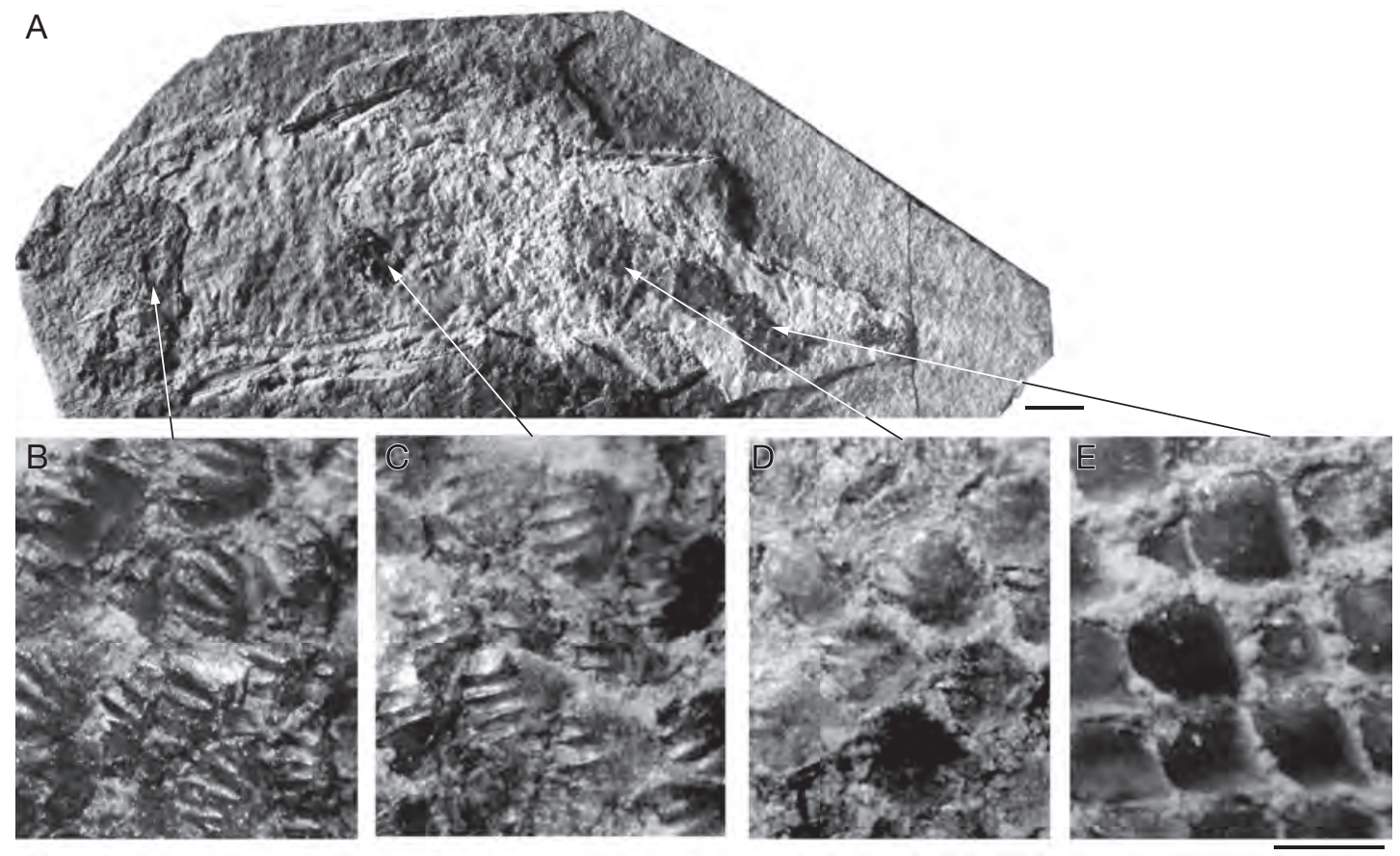

FIG. 13. - Euthacanthus macnicoli Powrie, 1864 NMS G.2013.8.1, an articulated moderate sized specimen from Tillywhandland: A, specimen before sectioning; B-E, light microscope views of articulated squamation patches; B, pectoral region; C, midflank, midbody; D, anterior to caudal peduncle between posterior dorsal and anal fin spines; E, tail lobe (zone Z1). Scale bars: A, 10 mm; B-E, 0.5 mm.

small individual from Tillywhandland. All scales on sectioned blocks (Fig. 15B-E) and from acid residues (Fig. 15F-M) show very similar morphology, being short, rhombic and 0.1-0.2 mm wide and long, with two strong parallel ridges running back from the anterior edge, fading out near the middle of the crown. Occasionally a third, weaker ridge is developed lateral to the central ridges; the ridges become lower on scales closer to the tail tip (Fig. 15D-E). The lateral parts of the crown plane are flat and smooth, and the lateral edges meet at a single posterior point which extends slightly beyond the posterior corner of the base. The scale neck is concave and relatively deep, with two or three large vascular canal openings on each of the four sides. The base is low and slightly concave. Histological sections through scales on the specimen (Fig. 15NP) show a small fin web scale with a wide pulp cavity in the primordium and a highly concave base (Fig. 15N), and a caudal scale and two similar scales abutting a fin spine showing three crown growth zones, Strangewebbe and wide vascular canals in the crown, and a flat base (Fig. 15O, P).

For the large partial articulated specimen NMS G.2010.7.39 (Fig. 16), flank scales show a wide range of size and crown ornament, with scales up to $1.8 \mathrm{~mm}$ wide. The smaller scales (Fig. 16A, B) are identical to those of average sized Euthacanthus macnicoli such as NMS G.2013.8.1 and NMS G.2010.7.42 (described above). On the scales with three or more ridges, some of the ridges bifurcate near the anterior edge of the crown (Fig. 16C$\mathrm{O})$. The anterior edge is sharp on most scales, only rarely rounded (Fig. 16I-J). Large scales have up to 12 ridges running back from the anterior edge of the crown, with the ridges becoming shorter, lower and weaker as the number increases. All scales have a flat smooth lateral region, although this is comparatively narrow on the larger scales with many ridges (e.g., Fig. 16L, N). The number 



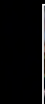


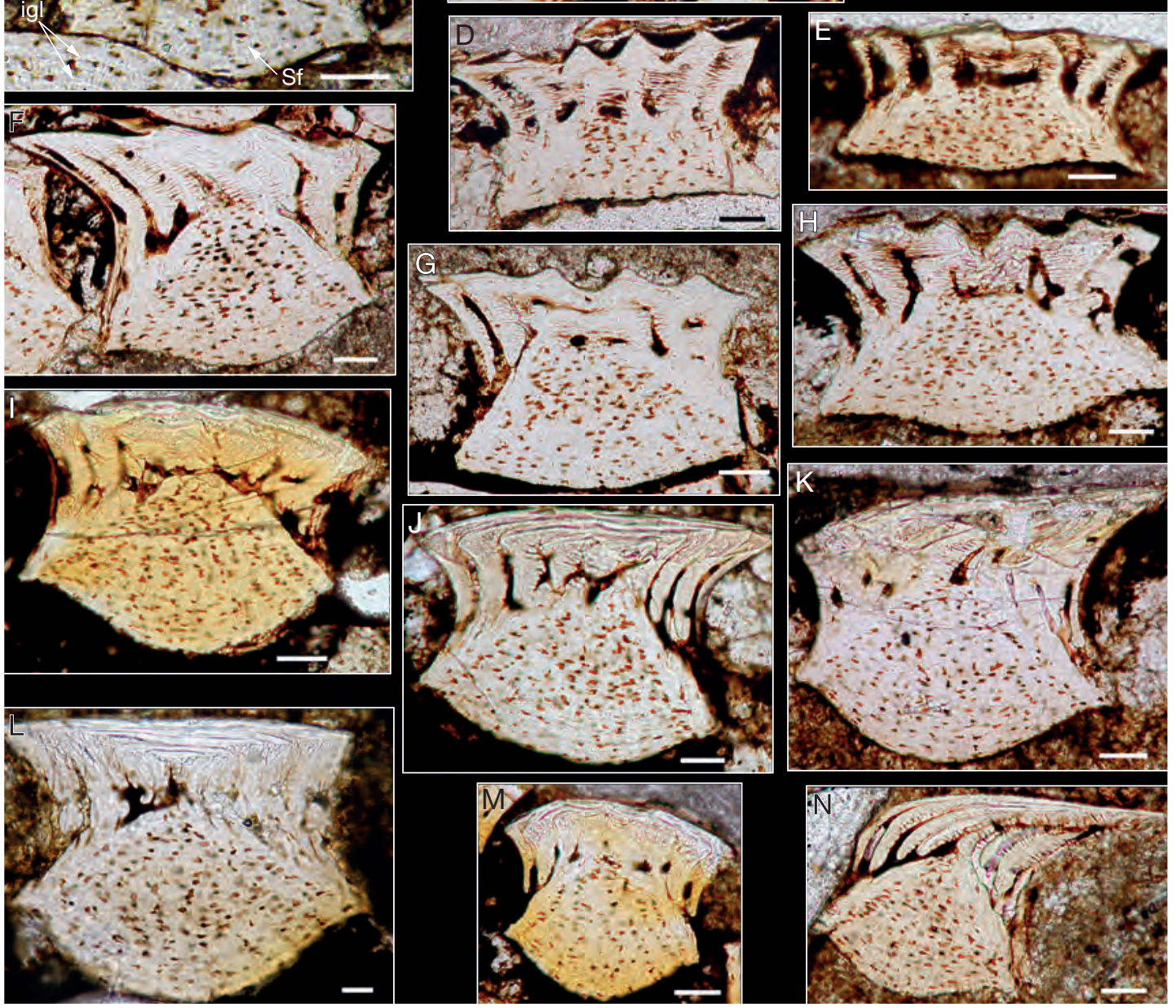

FIG. 14. - Euthacanthus macnicoli Powrie, 1864 NMS G.2013.8.1, thin sections of individual scales in serial sections of an articulated, moderate sized specimen from Tillywhandland: A-C, sections in the pectoral region; $\mathbf{A}$, vertical longitudinal section with three crown growth zones; B, median vertical longitudinal section along a groove between crown ridges; C, vertical transverse section with three growth zones; D, E, vertical transverse sections in the anterior midflank region; F-H, sections in the midbody midflank region; $\mathbf{F}$, oblique section; $\mathbf{G}, \mathbf{H}$, vertical transverse sections; I-K, sections in the posterior midflank region between the posterior dorsal and anal fin spines; I, vertical transverse section; J, K, vertical longitudinal section; L-N, sections in the caudal peduncle-midtail region; L, M, vertical transverse section; N, vertical longitudinal section. Abbreviations: bcl, bone cell lacunae; igl, incremental growth lines; m, mesodentine; Sf, Sharpey's fibres; Sg, Stranggewebe; vc, vascular canal. Scale bars: A, L, 0.05 mm; B-K, M, N, 0.1 mm.

of vascular canal openings on the neck increases with the number of growth zones. Scales from the ventral region are mostly large and very robust with worn crowns (Fig. 16H-N, ?P), and as shown by patches which remained articulated after acid treatment, were closely packed with posterior corners overlapping the scales behind (Fig. 16R). Specialized scales include pinnal scales, presumed 


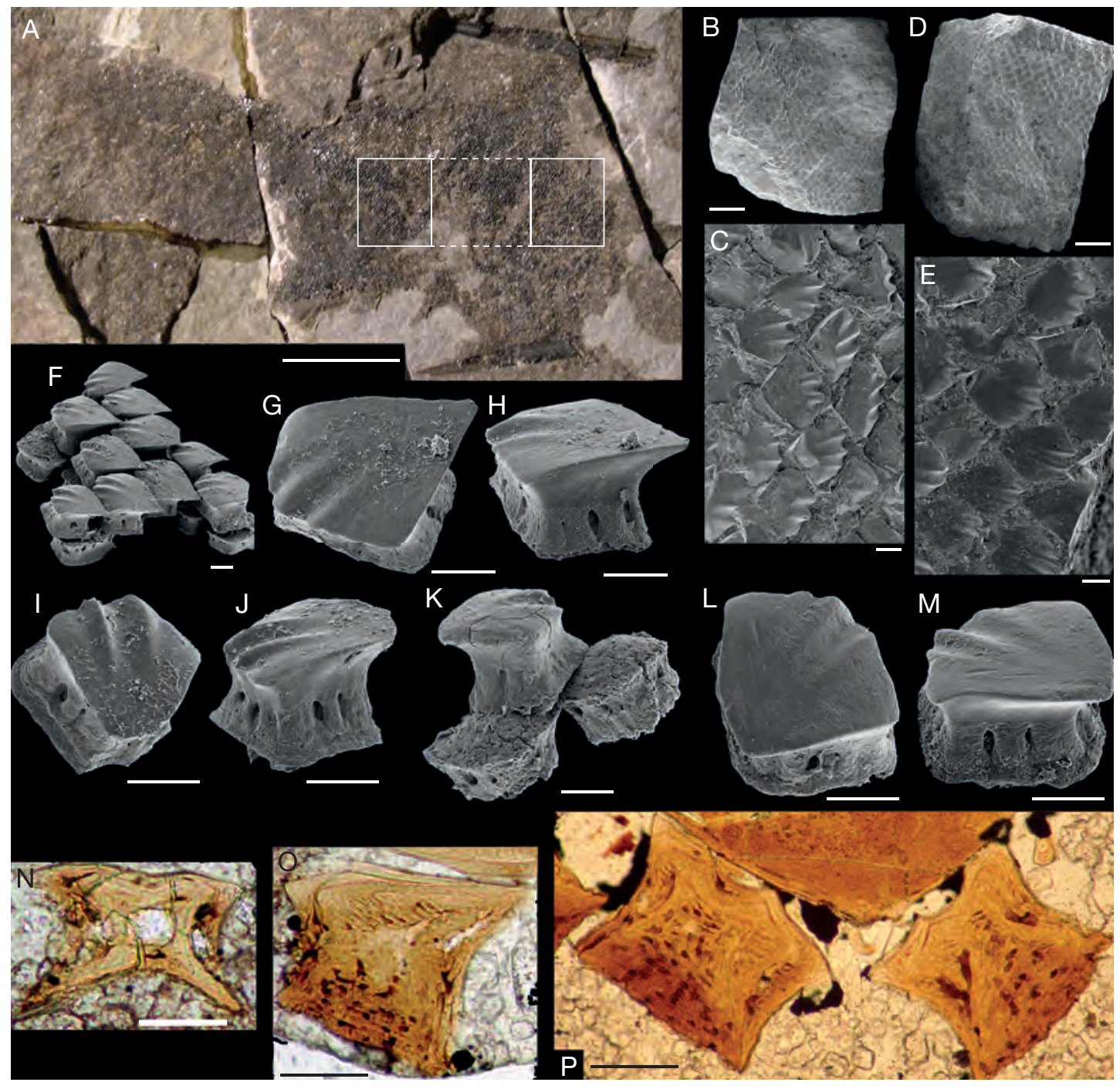

FIG. 15. - Euthacanthus macnicoli Powrie, 1864 specimen NMS G.2010.7.42, the rear half with the posterior dorsal and anal fin spines of a small articulated specimen from Tillywhandland: A, the specimen before thin sectioning with the anterior to the right; white lines shown the areas thin sectioned; B-M, SEM views of scales; B, C, squamation segment cut midflank below the posterior dorsal fin spine; $\mathbf{D}$, E, squamation segment cut at the middle of the caudal peduncle; $\mathbf{F}-\mathbf{M}$, scales in residues after acetic acid treatment of remainder of cut portion; $\mathbf{F}$, articulated patch of scales (both sides of fish compressed together); $\mathbf{G}, \mathbf{H}$, scale in crown and lateral view; I, J, scale in crown and lateral view; K, scale from one side of the body attached to two scales from the other side; L, M, scale in crown and posterolateral view; $\mathbf{N}-\mathbf{P}$, thin sections of scales; $\mathbf{N}$, vertical transverse section of a young fin web scale; $\mathbf{O}$, vertical longitudinal section of a fin web scale; $\mathbf{P}$, vertical transverse sections of two scales abutting a fin spine. Scale bars: A, $10 \mathrm{~mm}$; B, D, $1 \mathrm{~mm}$; C, E-P, $0.1 \mathrm{~mm}$.

to be from the ventral pectoral region, that have a strongly inclined crown (Fig. 16Q). A large mass of tiny scales was observed in the head region of NMS G.2010.7.39, of which nearly all are assign- able to Euthacanthus (Fig. 16S, T). However, some of the scales were shiny smooth-crowned scales probably from Mesacanthus mitchelli. The scale mass could have been overlain by the main speci- 


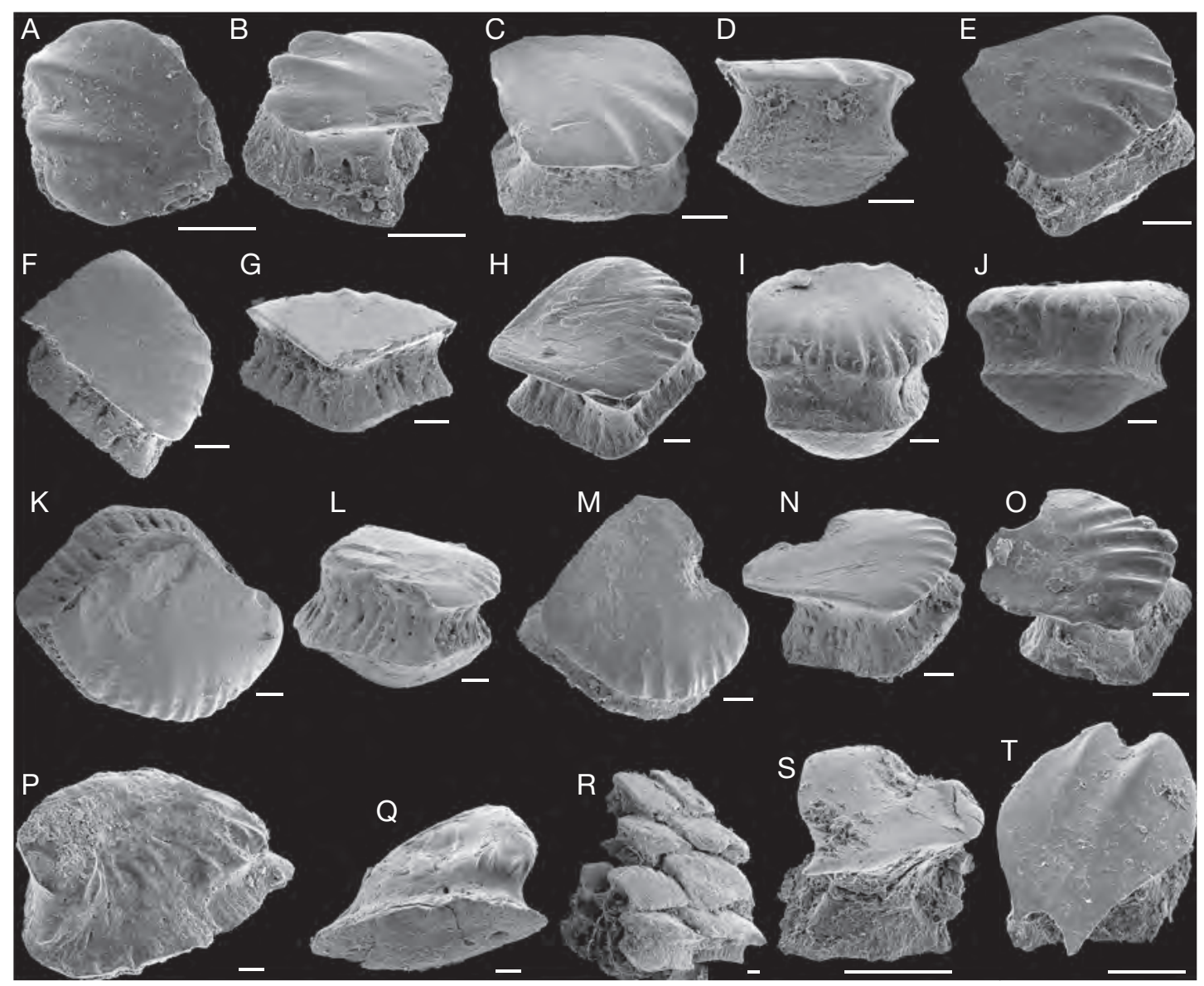

FIG. 16. - Euthacanthus macnicoli Powrie, 1864 specimen NMS G.2010.7.39, SEMs of scales from a large partial articulated specimen from Tillywhandland: A, B, scale in crown and posterolateral view; C-D, scale in crown and anterolateral view; E, scale in laterocrown view; $\mathbf{F}$, G, scale in crown and posterior view; H, scale in laterocrown view; I, J, scale in anterocrown and anterior view; K, L, scale in crown and lateral view; $\mathbf{M}, \mathbf{N}$, scale in crown and lateral view; $\mathbf{O}$, scale in laterocrown view; $\mathbf{P}$, scale in anterior view; $\mathbf{Q}$, scale in anterobasal view; $\mathbf{R}$, patch of articulated scales from venter in posterocrown view; $\mathbf{S}$, small scale from head region in posterior view; $\mathbf{T}$, small scale from head region in posterocrown view. Scale bars: $0.1 \mathrm{~mm}$.

men, or they could be oral or branchial scales. The tiny Euthacanthus scales could also have been some of the small scales forming the cheek squamation (Fig. 5C). They differ from normal flank scales in their small size, and in being narrow and elongate with a curving crown, and occasionally with two posterior crown points.

Serial thin sections of the NMS G.2010.7.39 counterpart (Fig. 17) show the histological structure of a good range of scales. Small flank scales (Fig. 17B-C) show the same structure as the scales on average sized fish. However, most of the scales are larger, with more growth zones (Fig. 17D-H), on average eight, but with some scales having more. Inner zones show that when younger, the scale morphology resembled average sized specimens of E. macnicoli with overlying layers having more ridges.

Flank scales from the disarticulated specimen NMS G.2010.7.43 (Fig. 18A) have four to six strong parallel crown ridges with a narrow smooth lateral edge. Specialised scales were also found in the acid residues, including stellate head scales 
(Fig. 18G-K), tuberculated head scales (Fig. 18I), and umbellate scales (Fig. 18J) which were positioned next to sensory canals. Histological structure (Fig. 18L-Q) is comparable with the scales from NMS G.2010.7.39.

\section{COMPARISON}

Berg (1940) raised the family Euthacanthidae to incorporate Euthacanthus and possibly Brachyacanthus. Miles (1966) also considered that Euthacanthus and Brachyacanthus were members of the same family as both forms have no teeth and a principle gill cover that did not cover the whole gill chamber. Miles (1966) also stated that Parexus and Climatius belonged in the same family (Climatiidae) as both forms had teeth in the lower jaw and the principal gill cover covered most, if not all of the gill chamber. Later, Miles (1973) suggested a close relationship between Euthacanthus, Parexus and Vernicomacanthus as these three forms have a complete reduction of the posterior lorical plate and the ventral pinnal laminae. Miles (1973) also stated that Euthacanthus differed from the other two forms as it lacked the anterior lorical, the median prepectoral and the anterior pinnal plates. Hanke \& Wilson (2004) suggested that Parexus had a close relationship to Euthacanthus due to the apparent unique character of the prepectoral spine being plate-like and well-separated from the pectoral fin spine. However, our investigations show that the "prepectoral plate" in Euthacanthus is more spine-like than previously recognized, and could possibly even be an admedian spine + plate. Fin spines of Euthacanthus differ from those of LORS taxa traditionally referred to the Climatiiformes in having smooth ridges, a character shared with ischnacanthiform, acanthodiform and diplacanthiform taxa.

Hanke \& Wilson (2004) stated that the new species collected from the Early Devonian of Canada made previous classification schemes too simplistic and that any attempt to reclassify the acanthodians would be premature, until work on describing new species from Canada and Russia, which was in progress, was completed, and that the work on reinterpreting the acanthodians already described from the Early Devonian of Canada and the Scottish Early Devonian (of which this is part) was also required. As noted earlier, neither of the recent cladistic analyses by Davis et al. (2012) and Zhu et al. (2013) show Euthacanthus closely allied to any other taxa.

Our detailed new information on histology of the scales of Euthacanthus macnicoli, as well as giving as comprehensive as possible detail on the variation over the body and between different sized fish, allows comparison of scale structure with some other LORS taxa that fall outside the well-supported ischnacanthiform and acanthodiform clades - Nostolepis scotica (Newton, 1892) (Burrow \& Turner 2010), Parexus recurvus Agassiz, 1845 (Burrow et al. 2013) and Climatius reticulatus Agassiz, 1845 (Burrow et al. in press) - as well as with some of the contemporary "spiny" taxa from the MOTH locality in Canada, including Obtusacanthus corroconis Hanke \& Wilson, 2004 and Lupopsyroides macracanthus Hanke \& Wilson, 2004 (Hanke \& Wilson 2004), Brochoadmones milesi Bernascek \& Dineley, 1977 (Hanke \& Wilson 2006), Kathemacanthus rosulentus Gagnier \& Wilson, 1996 (Hanke \& Wilson 2010) and Lupopsyrus pygmaeus Bernacsek \& Dineley, 1977 (Hanke \& Davis 2012). Histological studies have not yet been done on scales of LORS taxa Brachyacanthus and Vernicomacanthus. However, of the other listed taxa, only Euthacanthus and Nostolepis have the "typical acanthodian" histological scale structure with superposed crown growth zones, combined with Nostolepis-type histology sensu Gross (1971).

\section{BiOGEOGRAPHY}

None of the other main sources of articulated gnathostomes of Lochkovian age (MOTH local-

FIG. 17. - Euthacanthus macnicoli Powrie, 1864 NMS G.2010.7.39, thin sections of scales from a large partial articulated specimen from Tillywhandland: A, a group of scales in various orientations; B-H, sections through individual scales; $\mathbf{B}$, vertical longitudinal section with six crown growth zones; $\mathbf{C}$, vertical transverse section with three crown growth zones; $\mathbf{D}$, crown horizontal section with eight crown growth zones; $\mathbf{E}$, vertical transverse section through posterior part of scale with at least eight growth zones; $\mathbf{F}$, vertical transverse section through the anterior part of the scale with five crown growth zones; $\mathbf{G}$, vertical longitudinal section with seven crown growth zones; 



$\mathbf{H}$, midneck horizontal section showing vascular canal opening into lower crown. Abbreviations: bcl, bone cell lacunae; igl, incremental growth lines; m, mesodentine; Sf, Sharpey's fibres; Sg, Stranggewebe; vc, vascular canal. Scale bars: A, 0.25 mm; B-H, 0.1 mm. 

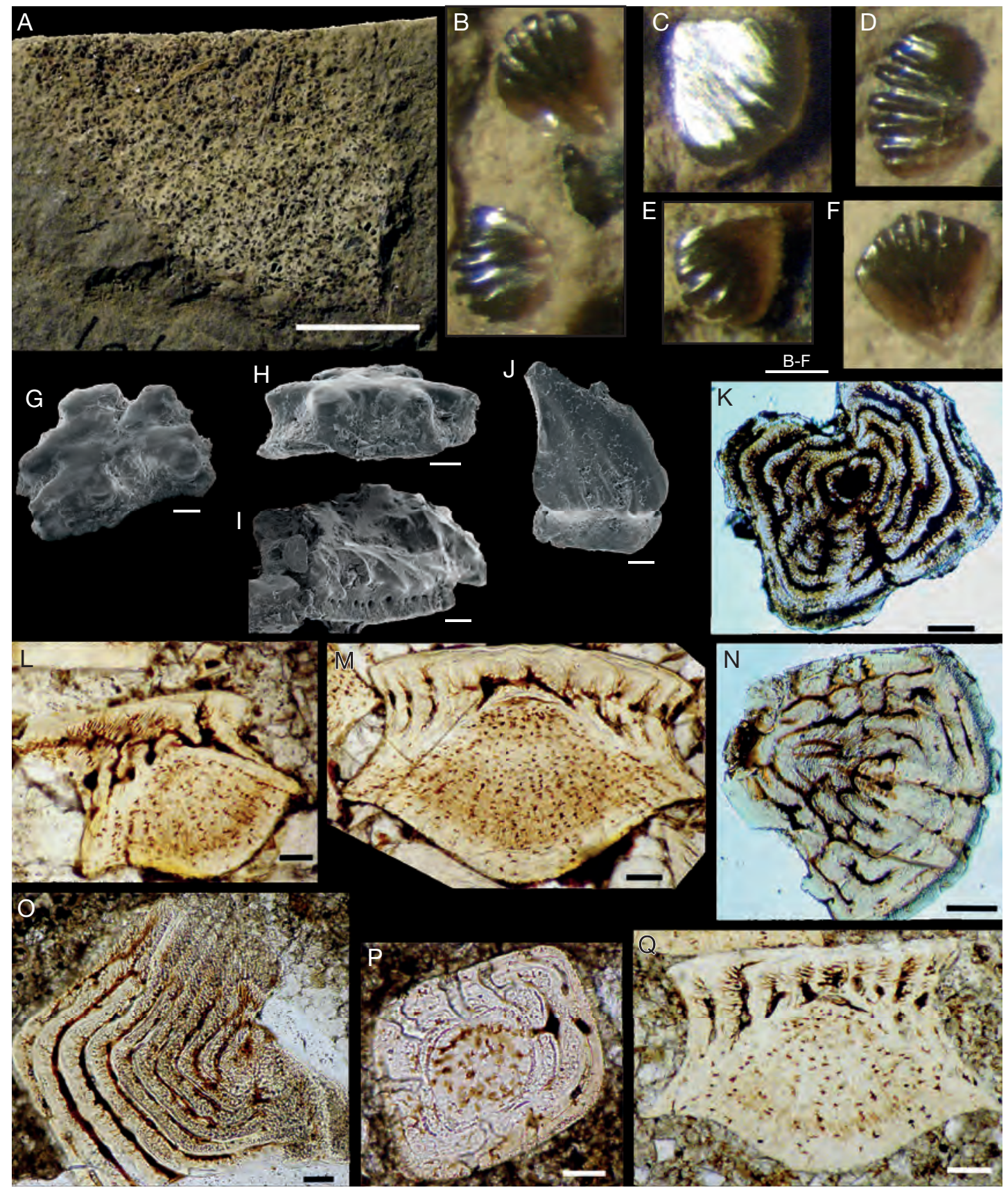

FIG. 18. - Euthacanthus macnicoli Powrie, 1864 NMS G.2010.7.43, a coprolitic/regurgitate patch of scales from a large individual from Tillywhandland: A, complete specimen; B-F, separate flank scales in matrix, viewed under a light microscope; G-J, SEM images of specialized scales; G, stellate head tessera in crown view; $\mathbf{H}$, stellate head tessera in lateral view; I, fractured tuberculated head scale in anterior view; $\mathbf{J}$, transitional or umbellate scale in anterocrown view; $\mathbf{K}-\mathbf{Q}$, thin sections of scales; $\mathbf{K}$, crown horizontal section of head scale or tessera; L, vertical longitudinal section with three crown growth zones with a vertical transverse section of a small Mesacanthus mitchelli Egerton, 1860 scale above anterior crown (to right); $\mathbf{M}$, vertical transverse section of scale with six crown growth 


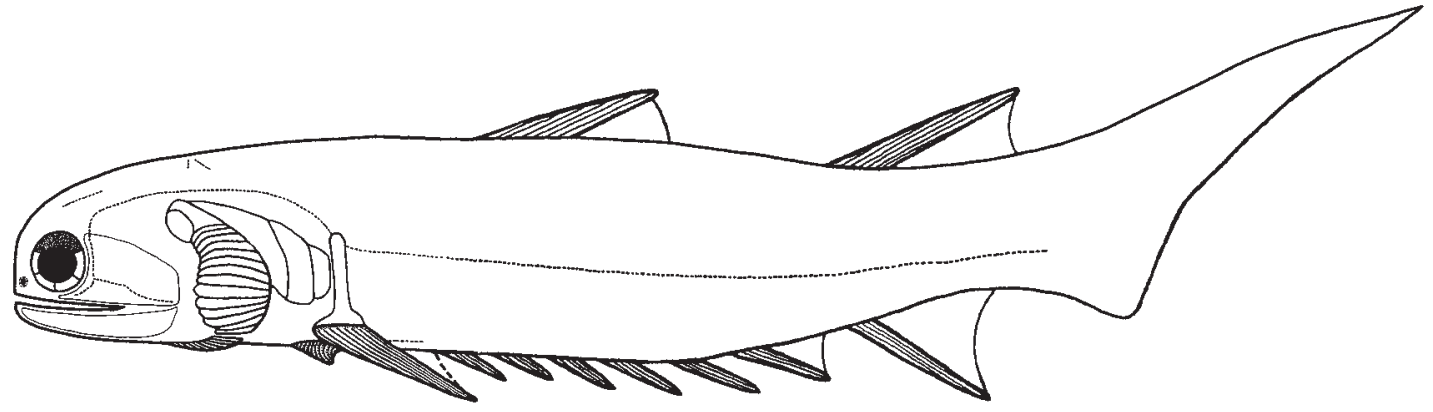

FIG. 19. - Euthacanthus macnicoli Powrie, 1864 Reconstruction of the whole fish in lateral view, much modified after Watson (1937: fig. $4 \mathrm{~A})$.

ity, Canada and Severnaya Zemlya) have yielded specimens of Euthacanthus macnicoli. However, the morphology and histology of the scales of E. macnicoli compare closely with some isolated scales from the Baltic region of Europe. As demonstrated above, this histological structure is of the Nostolepis-type. Variations within this grouping were further refined by Valiukevičius \& Burrow (2005) in order to delimit the genus Nostolepis s.s., which had scores of new species assigned to it over the last several decades (e.g., Valiukevičius 1994, 1998, 2003a, b). The scale histology for Euthacanthus macnicoli corresponds to that of Nostolepis s.s. Valiukevičius has erected many new Siluro-Devonian acanthodian taxa based on isolated scales, and several of the varieties which he assigned to Cheiracanthoides spp. are strikingly similar to those of Euthacanthus. Scales of Cheiracanthoides borealis Valiukevičius, 1994 (Valiukevičius 1994: figs 65.4, 66.1, 2, pl. 23, figs 1-5) from the Lochkovian-Pragian of Taimyr, Russia are most similar morphologically to those of Euthacanthus macnicoli s.l., having four to six parallel ridges with flat areas laterally on the crown. In the original description, the Taimyr scales are described as lacking Stranggwebe, but as shown by the hundreds of sections which we have of Euthacanthus macnicoli scales, this tissue is vis- ible only when sections are made directly through the Stranglakunae in the scales. Other scales with more numerous (13-21) short fine ridges on the anterior crown from a lower stratum in the same section in Taimyr, assigned to Cheiracanthoides rarus Valiukevičius, 1994 (Valiukevičius 1994: figs 71.1-3, 72.1, pl. 23, figs 6-8), resemble those of large specimens of E. macnicoli morphologically, but have only narrow canals in the scale crowns. Scales of Cheiracanthoides nativus Valiukevičius, 1998 (Valiukevičius 1998: pl. 1, fig. 16, 19, 20 , 21; pl. 9, figs 6-8; pl. 10, figs 1-9; pl. 11, figs 1-2) from the Lochkovian Stoniskiai Regional Stage of Lithuania, Latvia, Kaliningrad (Russia), and C. planus Valiukevičius, 1998 (Valiukevičius 1998: pl. 3, figs 9-11, 14, 15; pl. 9, figs 1-5) from the Pridoli-Lochkovian of the East Baltic and Byelorussia fit within both the morphological and histological variation shown by the scales of Euthacanthus spp. However, as recently shown by Burrow et al. (2013) it cannot be assumed that isolated scales with similar morphology and histology belong to the same species, genus or perhaps even class of fish. Our study has shown a wider range of body scale morphotypes for E. macnicoli than previously imagined, and future studies of isolated scale assemblages should encompass this variation in determining species composition.

zones; $\mathbf{N}$, low crown horizontal section of a flank scale; $\mathbf{O}$, crown horizontal section through an incomplete large scale showing nine or ten crown growth zones; $\mathbf{P}$, mid-neck horizontal section through a small flank scale; $\mathbf{Q}$, vertical transverse section with four crown growth zones. Scale bars: A, $10 \mathrm{~mm}$; B-F, $0.25 \mathrm{~mm}$; G-Q, $0.1 \mathrm{~mm}$. 


\section{CONCLUSIONS}

This work is part of a project to revise and expand descriptions of all the Scottish Devonian acanthodians, updating general morphological characters and incorporating new data to clarify classification of the acanthodians and their relationships with other groups of fishes. Previous cladistic approaches have been hampered by the lack of data on articulated acanthodians across the Old Red Sandstone continent. This problem is being addressed by various workers working particularly in the Siluro-Devonian of the Canadian MOTH locality and the Scottish Old Red Sandstone. Euthacanthus macnicoli (new reconstruction shown in Fig. 19) is important in this regard as many workers (e.g., Denison 1979) considered the species as one of the more "primitive" acanthodians, and more recently as a stem acanthodiform (Brazeau 2009), or the basal taxon of the osteichthyan stem lineage (Davis et al. 2012), or in a polytomy with Ptomacanthus, ischnacanthiforms, [Climatius + Brachyacanthus + Parexus], acanthodiforms and [stem chondrichthyan "acanthodians" + Chondrichthyes] (Zhu et al. 2013). Here we support the view that the species is not closely allied to the climatiids, and that Euthacanthus is the sole genus in the family Euthacanthidae. Work in progress on other LORS taxa should help to clarify relationships between the traditional "Acanthodii" and other early gnathostomes.

\section{Acknowledgements}

CJB acknowledges the support of the Queensland Museum for providing basic support facilities and SEM usage. We thank Mike Taylor and Stig Walsh at the National Museums of Scotland and Zerina Johanson at the Natural History Museum in London for allowing access to specimens in their care and Roger Jones for donating NHM P.67308 to the Natural History Museum thus allowing us to use it in our study. We also thank Philippe Janvier and an anonymous reviewer for their positive and useful comments, the editors Didier Merle and Emmanuel Côtez for their advice, and Gaël Clément for help in translating the abstract into French. This is a contribution to IGCP591: The Early to Middle Paleozoic Revolution, and IGCP596: Climate change and biodiversity patterns in the MidPalaeozoic (Early Devonian to Late Carboniferous).

\section{REFERENCES}

ADAMS L. A. \& EDDY S. 1949. - Comparative anatomy; an introduction to the vertebrates. J. Wiley, New York, vii, $520 \mathrm{p}$.

ANONYMOUS 1867. — Report of the Directors for 1866. Montrose Museum, Scotland: 3-11.

ANONYMOUS 1908. - Tribute to memory of Tealing geologist. Dundee Courier Monday 10 August: 5.

Armstrong M. \& Paterson I. B. 1970. - The Lower Old Red Sandstone of the Strathmore Region. Institute of Geological Sciences Report 70/12: 1-23.

BARKAS W. J. 1874. - II. List of Palæozoic Fishes. Geological Magazine (Decade II) 1: 542-553.

BENTON M. J. 1997. - Vertebrate palaeontology. 2nd edition, Chapman \& Hall, Melbourne, 452 p.

BERG L. S. 1940. - Classification of fishes both recent and fossil. Transactions of the Zoological Institute, Leningrad, USSR 5: 85-517. [85-345 in Russian]

BRAZEAU M. D. 2009. - The braincase and jaws of a Devonian "acanthodian" and modern gnathostome origins. Nature 457: 305-308.

BRAZEAU M. D. 2012. - A revision of the anatomy of the Early Devonian jawed vertebrate Ptomacanthus anglicus Miles. Palaeontology 55: 355-367.

BURROW C. J. \& YOUNG G. C. 1999. - An articulated teleostome fish from the Late Silurian (Ludlow) of Victoria, Australia. Records of the Western Australian Museum Supplement 57: 1-14.

Burrow C. J. \& Turner S. 2010. - Reassessment of "Protodus" scoticus from the Early Devonian of Scotland, in Elliott D. K., Maisey J. G., Yu X \& Miao D. (eds), Morphology, Phylogeny and Paleobiogeography of Fossil Fishes. Verlag Dr. Friedrich Pfeil, München: 123-144.

Burrow C. J., Newman M. J., Davidson R. G. \& Den BlaAuwen J. L. 2011. - Sclerotic plates or circumorbital bones in early jawed fishes? Palaeontology 54: 207-214.

Burrow C. J., Newman M. J., Davidson R. G. \& Den BlaAuwen J. L. 2013. - Redescription of Parexus recurvus, an Early Devonian acanthodian from the Midland Valley of Scotland. Alcheringa 37: 392-414.

Burrow C. J., Davidson R. G., Den BlaAuwen J. L. \& NewMan M. J. (in press). - Revision of Climatius reticulatus Agassiz, 1844 (Acanthodii, Climatiidae) from the Lower Devonian of Scotland, based on new histological and morphological data. Journal of Vertebrate Paleontology.

Davidson R. G. D. \& NEWMAn M. J. 2003. — James Powrie, chronicler of the Scottish Lower Devonian. Proceedings of the Geologists' Association 114: 243-246.

Davis S. P., Finarelli J. A. \& Coates M. I. 2012. - Acanthodes and shark-like conditions in the last common ancestor of modern gnathostomes. Nature 486: 247-250. 
DEAN B. 1907. - Notes on acanthodian sharks. American Journal of Anatomy 7: 211-222.

Denison R. 1979. — Acanthodii, in SCHultze H.-P. (ed.), Handbook of palaeoichthyology, 5. Gustav Fischer Verlag, Stuttgart, 62 p.

Dineley D. L. 1999. - Early Devonian fossil fishes sites of the Welsh Borderland, in Dineley D. L. \& MetCalF S. J. (ed.), Fossil fishes of Great Britain. Joint Nature Conservation Committee, Peterborough, UK: 107-144.

Franz-ODENDAAL T. A. 2011. - The ocular skeleton through the eye of evo-devo. Journal of experimental zoology. Part B, Molecular and developmental evolution 316: 393-401.

FrickHINGER K. A. 1991. — Fossilien-Atlas Fische. Mergus Verlag, Melle, 1088 p.

Gagnier P.-Y., Hanke G. F. \& Wilson M. V. H. 1999. - Tetanopsyrus lindoei gen. et sp. nov., an Early Devonian acanthodian from the Northwest Territories, Canada. Acta Geologica Polonica 49: 81-96.

Goodchild J. G. 1904. — V. The Older Deutozoic Rooks of North Britain. Geological Magazine (Decade V) 1: 591-602.

Graham-Smith W. 1936. — The tail of fishes. Proceedings of the Zoological Society of London 1936: 595-608.

Gross W. 1971. — Downtonische und Dittonische Acanthodier-Reste des Ostseegebietes. Palaeontographica A 136: 1-82.

GunTHER A. 1904. - The History of the Collections Contained in the Natural History Departments of the British Museum, Volume 1. Trustees of the British Museum, Longmans, London, xvii + 442 p.

Halstead L. B. 1969. - The Pattern of Vertebrate Evolution. Oliver \& Boyd, Edinburgh, 209 p.

Hanke G. F. \& Wilson M. V. H. 2004. - New teleostome fishes and acanthodian systematic, in ARRATia G., Wilson M. V. H. \& Cloutier R. (eds), Recent Advances in the Origin and Early Radiation of Vertebrates. Verlag Dr Friedrich Pfeil, München: 189-216.

Hanke G. F. \& Wilson M. V. H. 2006. - Anatomy of the early Devonian acanthodian Brochoadmones milesi based on nearly complete body fossils, with comments on the evolution and development of paired fins. Journal of Vertebrate Paleontology 26: 526-537.

HANKE G. F. \& DAVIS S. P. 2008. — Redescription of the acanthodian Gladiobranchus probaton Bernacsek \& Dineley, 1977, and comments on diplacanthid relationships. Geodiversitas 30 (2): 303-330.

HANKE G. F. \& DAVIS S. P. 2012. - A re-examination of Lupopsyrus pygmaeus Bernacsek \& Dineley, 1977 (Pisces, Acanthodii). Geodiversitas 34 (3): 469-487. http://dx.doi.org/10.5252/g2012n3a1

HaY O. P. 1902. - Bibliography and catalogue of the fossil vertebrata of North America. Bulletin of the United States Geological Survey 179: 1-868.
HeYler D. 1969a. - Vertébrés de l'Autunien de France. Cahiers de Paléontologie, Éditions du Centre national de la Recherche scientifique, Paris, 255 p.

Heyler D. 1969b. - Acanthodii, in Piveteau J. (ed.) Traité de Paléontologie. Tome IV, vol. 2: 21-70.

JANVIER P. 1996. — Early Vertebrates. Oxford University Press, Oxford, 393 p.

JARVIK E. 1977. - The systematic position of acanthodian fishes, in ANDrews S. M. \& MiLEs R. S. (eds), Problems in Vertebrate Evolution. Academic Press, London: 199-225.

LEHMAN J.-P. 1959. — L'évolution des vertébrés inférieurs. Dunod, Paris, 188 p.

LONG J. A. 1986. — New ischnacanthid acanthodians from the Early Devonian of Australia, with comments on acanthodian interrelationships. Zoological Journal of the Linnean Society 87: 321-339.

Miles R. S. 1966. - The acanthodian fishes of the Devonian Plattenkalk of the Paffrath trough in the Rhineland. Arkiv für Zoologi 18: 147-194.

MiLes R. S. 1970. — Remarks on the vertebral column and caudal fin of acanthodian fishes. Lethaia 3: 343-362.

Miles R. S. 1973. - Articulated acanthodian fishes from the Old Red Sandstone of England, with a review of the structure and evolution of the acanthodian shoulder-girdle. Bulletin of the British Museum (Natural History) Geology 24: 111-213.

Miller R. F. 2007. — Pterygotus anglicus Agassiz (Chelicerata: Eurypterida) from Atholville, Lower Devonian Cambellton Formation, New Brunswick, Canada. Palaeontology 50: 981-999.

Moy-Thomas J. A. 1939. — Palaeozoic Fishes. Methuen and Co. Ltd, London, 149 p.

Moy-Thomas J. A. \& Miles R. S. 1971. - Palaeozoic Fishes. Chapman and Hall, London, 259 p.

Newman M. J., Davidson R. G., Den Blaauwen J. L. \& Burrow C. J. 2011. - The Early Devonian acanthodian Euthacanthus gracilis from the Midland Valley of Scotland. Scottish Journal of Geology 47: 101-111.

Newman M. J., Davidson R. G., Den BlaAuwen J. L. \& Burrow C. J. 2012. - The Early Devonian acanthodian Uraniacanthus curtus n. comb. from the Midland Valley of Scotland. Geodiversitas 34 (4): 739-759. http://dx.doi.org/10.5252/g2012n4a2

O'CONnEll M. B. 1916. - The habitat of the Eurypterida. Bulletin of the Buffalo Society of Natural Sciences 11: 1-278.

PARK L. E. \& GIERLOWSKI-KordesCH E. H. 2007. — Paleozoic lake faunas: Establishing aquatic life on land. Palaeogeography, Palaeoclimatology, Palaeoecology 249: 160-179.

PATON R. L. 1976. - A catalogue of fossil vertebrates in the Royal Scottish Museum, Part 5, Acanthodii. Royal Scottish Museums, Information Series, Geology, 6, 40 p.

POWRIE J. 1864. - On the fossiliferous rocks of Forfarshire and their contents. Quarterly Journal of the Geological Society of London 47: 413-429. 
POWRIE J. 1870. - On the earliest known vestiges of vertebrate life; being a description of the fish remains of the Old Red Sandstone rocks of Forfarshire. Transactions of the Edinburgh Geological Society 1: 284-301.

POWRIE J. 1881. - Fossils, in WARden A. J. (ed.) Angus or Forfarshire the land and people, descriptive and historical, volume 2. Charles Alexander \& Co., Dundee: 160-172.

Prothero D. R. 1998. - Bringing fossils to life: an introduction to paleobiology. WCB/McGraw-Hill, Boston, viii $+457 \mathrm{p}$.

TRAQUaIR R. H. 1892. - L List of the Type and Figured specimens in the "Powrie Collection" of fossils. The Annals of Scottish Natural History 1: 31-39.

Traquair R. H. 1894. - Notes on Palaeozoic fishes. No. 1. Annals and Magazine of natural History 14, ser. 6: 368-374.

Trewin N. H. \& Davidson R. G. 1996. — An Early Devonian lake and its associated biota in the Midland Valley of Scotland. Transactions of the Royal Society of Edinburgh: Earth Sciences 86: 233-246.

UPENIECE I. 2011. - Palaeoecology and juvenile individuals of the Devonian placoderm and acanthodian fishes from Lode site, Latvia. Disertations Geologicae Universitas Latviensis 21: 1-221.

VALIUKEVIČIUS J. J. 1994. — Acanthodians and their stratigraphic significance, in CHERKESOVA S., KARATAjute-TalimaA V. \& Matukhin R. (eds), Stratigraphy and Fauna of the Lower Devonian of the Tareya Key Section (Taimyr). Nedra, Leningrad: 131-197, 236-243 (in Russian).

VALIUKEVIČIUS J. J. 1998. - Acanthodians and zonal stratigraphy of Lower and Middle Devonian in East Baltic and Byelorussia. Palaeontographica A 248: 1-53.

VALIUKEVIČIUS J. J. 2003a. - Devonian acanthodians from Severnaya Zemlya Archipelago (Russia). Geodiversitas 25 (1): 131-204.
Valiukevičius J. J. 2003b. - New Late Silurian to Middle Devonian acanthodians of the Timan-Pechora region. Acta Geologica Polonica 53: 209-245.

VALIUKEVIČIUS J. \& BURROW C. J. 2005. - Diversity of tissues in acanthodians with Nostolepis-type histological structure. Acta Palaeontologica Polonica 50: 635-649.

WaTSON D. M. S. 1937. — The acanthodian fishes. Philosophical Transactions of the Royal Society of London 228B: 49-146.

WiLSON H. M. \& ANDERSON L. I. 2004. - Morphology and Taxonomy of Paleozoic Millipedes (Diplopoda: Chilognatha: Archipolypoda) from Scotland. Journal of Paleontology 78: 169-184.

WOODWARD A. S. 1891. - Catalogue of the fossil fishes in the British Museum (Natural History), 2. British Museum (Natural History), London, 567 p.

WoOdWARd A. S. \& SHerborn C. D. 1890. - A catalogue of British fossil vertebrata. Dulau, London, $396 \mathrm{p}$.

YounG V. T. 1995. - Micro-remains from Early and Middle Devonian acanthodian fishes from the U.K. and their biostratigraphic possibilities. Ichthyolith Issues, Special Publications 1: 65-68.

Zhu M., Yu X., Ahlberg P. E., Choo B., Lu J., QiaO T., QU Q., ZHaO W., Jia L., BlOM H. \& ZHU Y. 2013. - A Silurian placoderm with osteichthyan-like marginal jaw bones. Nature 502: 188-193.

ZiDEK J. 1976. - Kansas Hamilton Quarry (Upper Pennsylvanian) Acanthodes, with remarks on the previously reported North American occurrences of the genus. The University of Kansas Paleontological Contributions Paper 83: 1-41.

ZIDEK J. 1980. - Acanthodes lundi, new species (Acanthodii), and associated coprolites from uppermost Mississippian Heath Formation of central Montana. Annals of the Carnegie Museum 49: 49-78.

ZIDEK J. 1985. - Growth in Acanthodes (Acanthodii: Pisces) data and implications. Paläontologische Zeitschrift 59: 147-166. 
